\title{
Evaluating tribunal adjudication: administrative justice and asylum appeals
}

\author{
Robert Thomas \\ School of Law, University of Manchester
}

This article examines the development, operation and reform of the tribunal system responsible for determining appeals against the refusal of refugee status by the Home Office. Consideration of this particular appellate system is situated within a broader discussion of the criteria and values against which tribunal adjudication systems may be evaluated. By examining asylum appeals, light is shed on the theory and practice of administrative justice with regard to: the problematic nature of ensuring accuracy in tribunal decision-making; the tensions under which appeal procedures operate; the importance of onward appeal rights; and the role of tribunals in policy implementation. The article argues that recent reform of the asylum appeal process, including the introduction of a single tier of appeal, the Asylum and Immigration Tribunal, by the Asylum and Immigration (Treatment of Claimants, etc) Act 2004 and restrictions on legal aid, has been motivated by political considerations and may increase the difficulties in operating an effective appeal process.

\section{INTRODUCTION}

Over recent years, the tension between the United Kingdom's legal obligations, under both the Refugee Convention and the European Convention on Human Rights (ECHR), toward foreign nationals seeking refuge and the political imperative to maintain effective immigration control has prompted continuous legal revolution in the administrative law processes governing the determination of asylum claims. ${ }^{1}$ In particular, the tribunal system which decides appeals against initial decisions refusing asylum has been continually

- I would like to thank Charles Blake, Tony Bradley, Neville Harris and Richard Rawlings for their comments on a draft of the article. I would also like gratefully to acknowledge financial assistance from the British Academy. The usual disclaimer applies. 1. According to the Refugee Convention 1951, art 1A, a refugee is someone who 'owing to a well-founded fear of being persecuted for reasons of race, religion, nationality, membership of a particular social group, is outside the country of his nationality and is unable, or owing to such fear, is unwilling to avail himself of the protection of that country'. Article 3 of the ECHR prohibits torture or inhuman or degrading treatment or punishment while art 8 provides for the right to private and family life. It is important to distinguish between 'refugee status', which means that an individual has been recognised as a refugee under the Refugee Convention and is entitled to rights under that Convention such as family reunion, and 'asylum', which simply means protection from the risk of ill-treatment or torture. 
reformed to ensure that unmeritorious claimants are not able to delay removal, while at the same time providing independent judicial oversight of executive decision-making. ${ }^{2}$ The most recent culmination of this trend is the Asylum and Immigration (Treatment of Claimants, etc) Act 2004, which replaces the established two-tier appeal structure, under which appeals were determined initially by an adjudicator of the Immigration Appellate Authority (IAA) and then on appeal by the Immigration Appeal Tribunal (IAT), with a single tier of appeal, the Asylum and Immigration Tribunal (AIT). ${ }^{3}$ In addition, the government has simultaneously introduced restrictions on publicly funded representation available to asylum appellants.

The objective of this article is to examine the operation of the system for determining asylum appeals and consider the impact of these reforms. This task raises a number of questions. What procedures are used in appeals? What is the role of representation? What is the quality of decision-making? What is the scope of onward avenues of legal challenge? What was the impetus behind the move to a single tier of appeal and the legal aid restrictions?

While such questions are specific to this particular appeal system, consideration of asylum appeals also poses a broader question: how are administrative lawyers to understand and evaluate tribunal adjudication systems? There can be little doubt concerning the relevance of this inquiry. After all, tribunals determine a considerably higher number of appeals than the volume of claims for judicial review received by the Administrative Court. ${ }^{4}$ If administrative lawyers are to appreciate and subject to critical scrutiny the operation of legal mechanisms overseeing executive activity other than judicial review, then tribunals provide an obvious institutional focus. The task of evaluating tribunal adjudication systems, however, requires a different methodology from that of traditional court-centred administrative law scholarship. Rather than analysing the development of legal principles in a handful of higher court judgments, attention needs to be focused upon the management of mass adjudication processes in order to identify the competing pressures under which a tribunal system functions. Furthermore, it is always necessary to situate the design, operation and reform of a tribunal system within its broader administrative and policy context. ${ }^{5} \mathrm{~A}$ study of asylum appeals may

2. See Asylum and Immigration Appeals Act 1993; Asylum and Immigration Act 1996; Immigration and Asylum Act 1999; Nationality, Immigration and Asylum Act 2002; Asylum and Immigration (Treatment of Claimants, etc) Act 2004.

3. This is despite the proposal of the Leggatt review of tribunals to establish a unified tribunal service based on the two-tier appeal model. See Leggatt Report Tribunals for Users: One System, One Service (2001); Department for Constitutional Affairs Transforming Public Services: Complaints, Redress and Tribunals $(\mathrm{Cm} 6243,2004)$. 4. While the volume of judicial review claims has been increasing - in 2003, there were 5,949 claims - it is extremely small when compared with the workload of the large tribunal systems. In 2003, tribunals under the supervision of the Council on Tribunals decided just over 600,000 appeals. The immigration and asylum appeal system, which determined over 150,000 appeals, now comprises the second largest tribunal system after the social security appeal system. See Department for Constitutional Affairs Judicial Statistics Annual Report 2003 (Cm 6251, 2004); Council on Tribunals Annual Report 2003/04 (HC 750, 2003-04).

5. Cf R E Wraith and P G Hutchesson Administrative Tribunals (London: Allen \& Unwin, 1973) p 17: 'The British constitution tries to keep law and politics apart ... but administrative tribunals inhabit a twilight world where the two intermingle.' 
then give some insight into the political context within which tribunal systems operate and also shed some light on the role of law in the administration of asylum policy.

\section{BACKGROUND: ASYLUM AND APPEALS}

The asylum appeal system has attracted interest in recent years for a number of reasons. First, by definition each asylum claim and appeal raises questions of human rights that are fundamental to the immediate future of the individual concerned. Secondly, there has been an increased number of asylum applicants. In 1986, for instance, there were 3,900 asylum claims; by 1995 , this figure had increased to 44,000 and peaked at 84,130 in 2002 (see below Table 1). In 2002, the Immigration and Nationality Directorate (IND) of the Home Office made 83,540 initial decisions and over 540 adjudicators (now immigration judges) determined 64,405 appeals; in 2003, these figures were 64,940 and 81,725 respectively. ${ }^{\circ}$ A direct consequence of the increase in applications has been the increased costs of operating the system. In 2002-03, IND spent $£ 1.86$ billion on all its operations, including $£ 1.07$ billion supporting and accommodating asylum applicants. The IAA spent $£ 101$ million handling appeals while publicly funded representation cost $£ 174$ million. ${ }^{7}$ Thirdly, there is the especially sensitive and politicised nature of immigration control. The caseload of this mass administrative justice system is, after all, dependant on population movements in the present 'age of migration' ${ }^{8}$ International instability and conflict have to a large degree been responsible for the volume of people seeking refuge; the 1990s was, after all, 'a decade of extraordinary human displacement'. ' At the same time, there has been an increased desire of people from developing countries for a better standard of living and governments have been compelled to pay greater attention to public concerns of asylum abuse and the need to maintain legitimate immigration controls.

6. Home Office Asylum Statistics 2002 and 2003 . Of the approximately 540 immigration judges, around 400 are part-time and the remainder work full-time.

7. National Audit Office Improving the Speed and Quality of Asylum Decisions ( $\mathrm{HC}$ 535, 2003-04) pp 1 and 4; Department for Constitutional Affairs Proposed Changes to Publicly Funded Immigration and Asylum Work (London: DCA, 2003). In 2003-04, the cost of providing legal aid for immigration and asylum cases was $£ 203$ million: $432 \mathrm{HC}$ Official Report (6th series) written answers col 165W, 15 March 2005.

8. S Castles and M J Miller The Age of Migration: International Population Movements in the Modern World (London: Palgrave, 3rd edn, 2003).

9. A C Helton The Price of Indifference: Refugees and Humanitarian Action in the New' Century (Oxford: Oxford University Press, 2002) p 18. 
Table 1: Asylum decisions and IAA appeals 2000-04 ${ }^{10}$

\begin{tabular}{|l|l|l|l|l|l|}
\hline & 2000 & 2001 & 2002 & 2003 & 2004 \\
\hline $\begin{array}{l}\text { Asylum claims } \\
\text { lodged }\end{array}$ & 80,135 & 71,365 & 84,130 & 49,405 & 33,930 \\
\hline $\begin{array}{l}\text { Number of } \\
\text { initial decisions }\end{array}$ & 109,205 & 119,015 & 83,540 & 64,940 & 46,035 \\
\hline $\begin{array}{l}\text { Grants of } \\
\text { refugee status }\end{array}$ & 10,375 & 11,180 & 8,270 & 3,865 & 1,515 \\
\hline $\begin{array}{l}\text { Grants of } \\
\text { ELR/HP/DL" }\end{array}$ & 11,495 & 19,845 & 20,135 & 7,210 & 3,995 \\
\hline $\begin{array}{l}\text { Refusals of } \\
\text { refugee status } \\
\text { and ELR/HP/DL }\end{array}$ & 75,680 & 87,990 & 55,130 & 53,865 & 40,525 \\
\hline $\begin{array}{l}\text { Appeals } \\
\text { determined by } \\
\text { IAA } \\
\text { Adjudicators }\end{array}$ & 19,395 & 43,415 & 64,405 & 81,725 & 55,975 \\
\hline $\begin{array}{l}\text { Appeals allowed } \\
\text { (success rate \%) }\end{array}$ & $\begin{array}{l}3,340 \\
(17 \%)\end{array}$ & $\begin{array}{l}8,155 \\
(19 \%)\end{array}$ & $\begin{array}{l}13,875 \\
(22 \%)\end{array}$ & $\begin{array}{l}16,070 \\
(20 \%)\end{array}$ & $\begin{array}{l}10,845 \\
(19 \%)\end{array}$ \\
\hline Removals & 9,000 & 9,285 & 10,740 & 13,005 & 12,430 \\
\hline
\end{tabular}

The development of successive statutory asylum appeal systems has in large part been an attempt to respond to the increasing number of applications. Before the creation of full in-country appeal rights in 1993, the courts, concerned at the poor quality of primary decisions, insisted that they be subject to 'the most anxious scrutiny'. ${ }^{2}$ As the number of judicial review challenges increased, the government conceded a right of appeal to the existing immigration appeals system. ${ }^{13}$ The volume of asylum appeals increased throughout the 1990s and asylum came to displace immigration appeals (eg by students, family visitors and for settlement) with the consequence that measures aimed at dealing with asylum have also restricted ordinary immigration appeal rights.

For applicants, the establishment of appeal rights had clear advantages as it entitled them to an independent de novo merits appeal which afforded them a

10. Home Office Asylum Statistics 2000-2004. These figures exclude dependants. The number of initial decisions and appeals in a particular year do not necessarily relate to the claims lodged in the same year.

11. Exceptional leave to remain (ELR) is a subsidiary status and has been replaced by Humanitarian protection (HP) and Discretionary leave (DL).

12. Bugdaycay v Secretary of State for the Home Department [1987] AC 514 at 531, per Lord Bridge of Harwich.

13. On the development of the immigration appeals system, see Report of the Committee on Immigration Appeals (Cmnd 3387, 1967); J M Evans Immigration Law (London: Sweet \& Maxwell, 2nd edn, 1983) pp 327-374; S Juss Immigration, Nationality and Citizenship (London: Mansell, 1993) pp 124-143. 
greater degree of participation in the decision-making process. As in other tribunal systems, a right of appeal provides appellants with the opportunity of presenting a well-prepared claim and adducing additional evidence in support of a favourable decision. In light of the difficult and uncertain fact-finding exercise involved in asylum decision-making and the possibility that initial decision-making may be inadequate, appeal rights have been of considerable importance to appellants. There were also advantages for the government. The establishment of a right of appeal provided government with a means of legitimising executive decision-making by having external legal control but without incurring the expense and delay of judicial review proceedings. The government was also able to establish a legal regime more appropriate to the needs of this policy domain; appeal procedural rules have, for instance, routinely specified shorter time limits than those applicable in judicial review proceedings in order to ensure quick decision-making.

The tribunal system did not, however, process appeals as quickly as initially envisaged. ${ }^{14}$ As the number of applications increased throughout the 1990 s, new processes were introduced into the appeal process to ensure that weak and unmeritorious claims could be filtered out quickly. For instance, the 1993, 1996 and 1999 Acts enabled the Home Office to certify certain claims as manifestly unfounded with the consequence that appellants could appeal to an adjudicator but did not have any onward right of appeal to the IAT. ${ }^{15}$ Appellants could nevertheless apply for judicial review in a wide range of circumstances. ${ }^{16}$ One feature of the system has then been the introduction of successive reforms to ensure that unmeritorious appellants are not able to delay removal, which has in turn led to increased complexity in the statutory regime. At the same time though the government has expanded the grounds on which appellants may challenge removal through the introduction of a separate human rights appeal which coincided with the coming into force of the Human Rights Act 1998. ${ }^{17}$

The determination of asylum claims is currently made through the following procedure. ${ }^{18}$ First, a foreign national present - either legally or illegally - in the United Kingdom applies to either an immigration officer at a port of entry (a port application) or the Home Office (an in-country application) for refugee status under the Refugee Convention or humanitarian protection (HP) or discretionary leave (DL) under the ECHR. The applicant will be interviewed and the file forwarded to an IND caseworker. ${ }^{19}$ If the claim is allowed, then the claimant will be awarded either refugee status and/or indefinite or limited leave

14. KPMG Peat Marwick Review of Asylum Appeals Procedure (London: Home Office and Lord Chancellor's Department, 1994).

15. Asylum and Immigration Appeals Act 1993, Sch 2, para 5; Asylum and Immigration Act 1996, s 1; Immigration and Asylum Act 1999, Sch 4, para 9.

16. $R$ Thomas 'The Impact of Judicial Review on Asylum' [2003] PL 479.

17. Immigration and Asylum Act $1999, \mathrm{~s} 65(1)$. See now the Nationality, Immigration and Asylum Act 2002, s 84(1).

18. For more detailed accounts, see $M$ Symes and $P$ Jorro Asylum Law and Practice (London: LexisNexis, 2003) pp 408-497; D Stevens UK Asylum Law and Policy: Historical and Contemporary Perspectives (London: Sweet \& Maxwell, 2004) pp 221-262.

19. Despite this being the only practicable way of managing decision-making, in strict constitutional terms the whole system is conducted by the Secretary of State; for instance, the Immigration Rules (HC 395, 1994) r 328 state that all asylum applications will be 
to remain. If denied, then a 'reasons for refusal letter' will be issued together with removal directions. A refusal decision will generate a right of appeal on both asylum and human rights grounds during which the claimant will not

\section{Figure 1: Appellate process introduced by the Nationality, Immigration and} Asylum Act 2002, Pt V

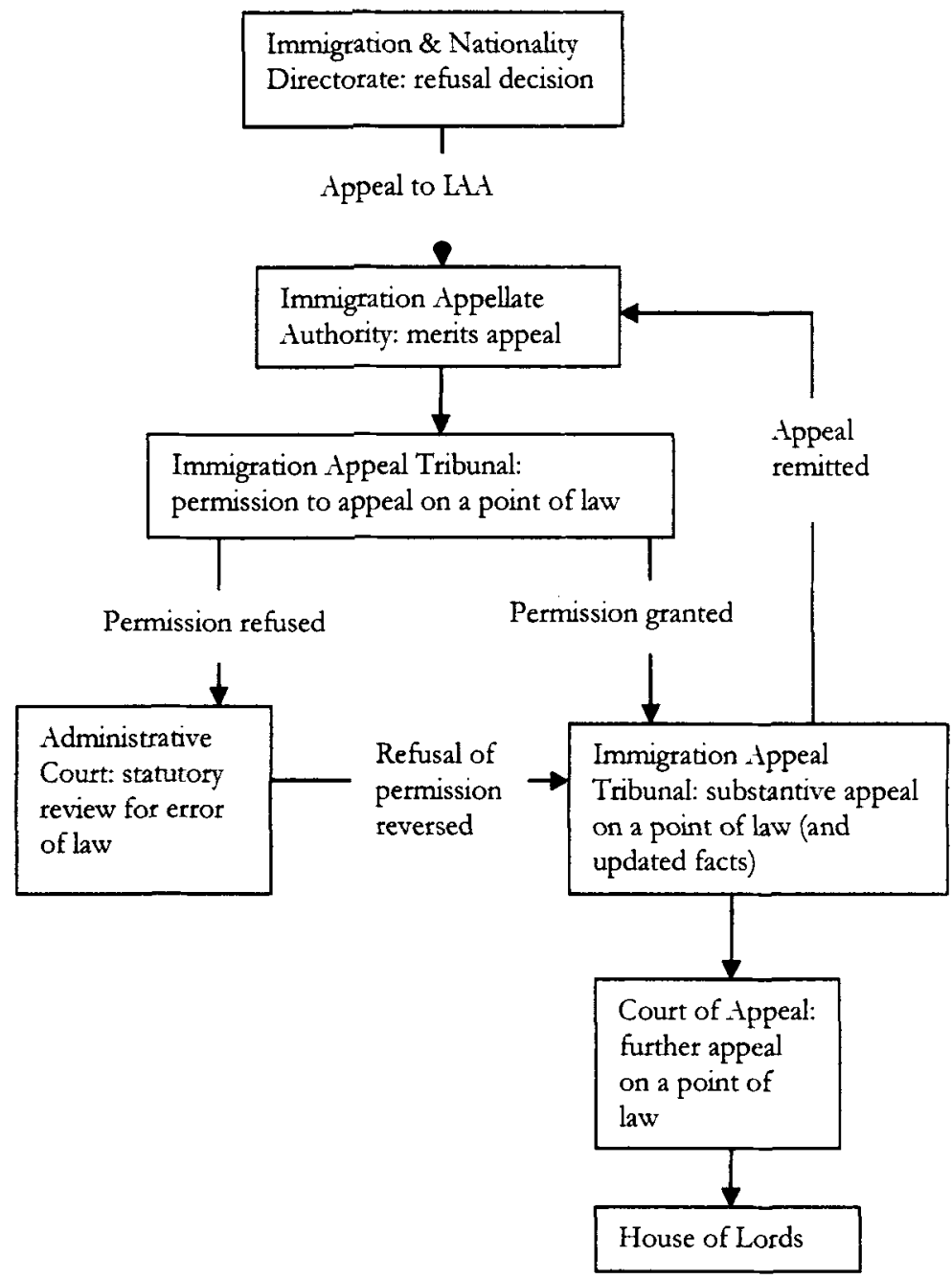

determined by the Secretary of State in accordance with the United Kingdom's obligations under the Refugee Convention and Home Office 'reasons for refusal letters' habitually contain phrases such as 'the Secretary of State has noted your claim that you were tortured' even though they are signed and written by IND caseworkers. 
normally be removed. ${ }^{20}$ Appeals are determined de novo usually after an oral hearing with representation. Under previous appeal regimes, first instance appeals were determined by a single legally qualified adjudicator and both parties - the claimant and the Secretary of State - could pursue a further appeal, with permission, to the IAT which could allow, dismiss or remit the appeal for a re-hearing (see below Figure 1). Under the 2004 Act, claimants have only one right of appeal to the new single-tier appellate body, the AIT, where the appeal will be determined by an immigration judge, whose decision may be reviewed by the Administrative Court (see below Figure 2). ${ }^{21}$ If a claim is

\section{Figure 2: Appellate process introduced by the Asylum and Immigration (Treatment of Claimants, etc) Act 2004, s 26}

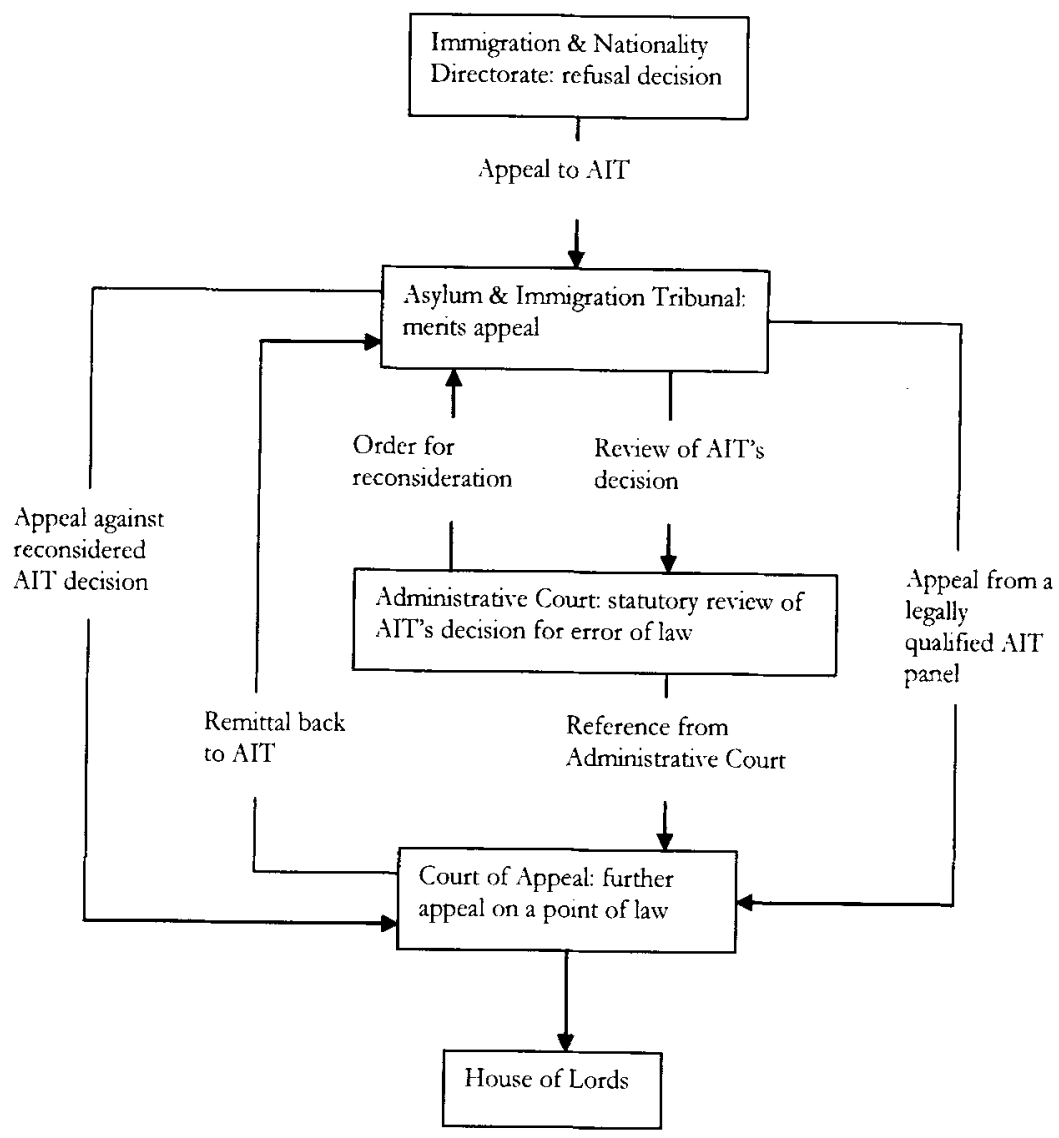

20. Nationality, Immigration and Asylum Act 2002, s 78. Section 84 of the 2002 Act also lists the grounds on which an appeal may be lodged. See further R Thomas 'Asylum appeals overhauled again' [2003] PL 260.

21. Asylum and Immigration (Treatment of Claimants, etc) Act 2004, s 26. 
ultimately unsuccessful, then removal should follow. Refused claimants may, however, make further representations that a fresh claim ought to be entertained owing to a change of circumstances. Alternatively, the Secretary of State may exercise his extra-statutory discretion to allow the claimant to remain.

In some respects, the asylum appeal process shares similarities with other tribunal systems, such as those in the social-welfare context. It is a high-volume, fact-based jurisdiction. The procedure exhibits a high degree of compulsion: claimants have little alternative but to comply with the process. There is also frequently little, if any, scope for the parties to achieve a compromise solution or to 'split the difference' because the decisions are binary: removal of the claimant is either contrary to the Refugee Convention and/or the ECHR or it is not. Furthermore, as with other administrative-legal adjudication systems, asylum decision-making is distinguished from ordinary civil litigation because of the underlying public interest in the decision-making process. A related point is that because the jurisdiction has its remit in administrative law, decisionmakers - both IND caseworkers and the appellate authorities - are not bound by the rules of evidence in civil litigation but must take into account all relevant considerations when assessing the risk of persecution or torture on return. ${ }^{22}$

Asylum adjudication also possesses some features which distinguish it from other systems. First, in contrast with other tribunal systems in which the rate at which refused claimants challenge negative decisions is typically quite low, asylum adjudication is characterised by an exceptionally high rate of challenge, perhaps the highest for any adjudicatory system, which has been described as a 'culture of pervasive challenge'. ${ }^{23}$ Secondly, the determination of claims is not dependant upon the establishment of historical facts but involves an assessment of the current risk of persecution or ill-treatment that a claimant might receive if returned to their country of nationality. Thirdly, owing to the need to assess the risk on return in light of an often changing factual background, it is a 'fundamental precept of our asylum law' that the appeal process is not confined to an examination of whether the primary decision was correct but must take into account any new factual developments such as the current political situation in the appellant's country of origin. ${ }^{24}$ This appeal process is therefore properly to be regarded as an 'extension of the

22. See especially Karanakaran $v$ Secretary of State for the Home Department [2000] 3 All ER 449 where, at 479 , Sedley $L J$ explained that: ' $[t]$ he question whether an asylum claim falls within the convention is not a head-to-head litigation issue. Testing a claim ordinarily involves no choice between two conflicting accounts but an evaluation of the intrinsic and extrinsic credibility, and ultimately the significance, of the applicant's case ... Such decision-makers, on classic principles of public law, are required to take everything material into account.'

23. Leggatt, above n 3, Pt II, 'The Immigration Appellate Authorities', para 22. For example, Social Security Appeal Tribunals have the largest caseload of any appellate system with some 230,000 appeals per year but this only represents around $1 \%$ of all initial decisions; by contrast, the proportion of asylum refusal decisions that are appealed was $80 \%$ in 2002 and $74 \%$ in 2003 . For a recent study of the failure of welfare applicants to challenge adverse decisions, see D Cowan and S Halliday The Appeal of Internal Review: Law, Administrative Justice and the (non-) emergence of disputes (Oxford: Hart Publishing, 2003).

24. GH v Secretary of State for the Home Department (former KAZ-country conditions - effect) Iraq CG [2004] UKIAT00248, para 26. See also Nationality, Immigration and Asylum Act 2002, s 85(4). 
decision-making process' rather than simply as a means of reviewing decisions already taken. ${ }^{25}$

A further distinctive feature of asylum adjudication is that the burden to be discharged by the claimant - is there a reasonable degree of likelihood that the claimant will face persecution on return to their country of nationality ${ }^{26}$ - is lower than the balance of probabilities test adopted in civil litigation because of the difficulties in establishing a claim and the adverse consequences of an incorrect refusal decision. While the burden is on the claimant to prove their claim, there is, however, a 'mutually owed, two-way, obligation' of fair dealing and co-operation between the claimant and the host state which arises from 'the very circumstances in which protection is sought and offered': the claimant alone possesses almost all the relevant personal knowledge concerning their asylum claim, while the state is better placed to collect evidence concerning general country conditions. ${ }^{27}$ As the Tribunal has noted, this mutual obligation together with the lower standard of proof dictates that asylum adjudication is 'a unique jurisdiction'. 28

\section{EVALUATING ASYLUM APPEALS}

What then are the criteria by which tribunal adjudication systems may be evaluated? An obvious starting point is provided by the Franks Report which stated that tribunals should be informed by the values of openness, fairness and impartiality. ${ }^{29}$ While this report enabled tribunals to become more firmly embedded within the judicial system, the values it espoused have, however, been subject to criticism. It has been argued that Franks only offered a set of traditional court values that tribunals were expected to satisfy. ${ }^{30}$ Franks

25. Sandralingham and Ravichandran $v$ Secretary of State for the Home Department; Rajendrakumar $v$ Immigration Appeal Tribunal and Secretary of State for the Home Department [1996] Imm AR 97 at 112, per Simon Brown LJ. In Secretary of State for the Home Department v SK (starred determination) [2002] UKIAT05613, para 20, the IAT (chaired by Collins J) expressed disagreement with the view that the appeal process is an extension of the decision-making process 'since it may seem to suggest that the appellate authority is somehow to be regarded as being part of the administrative process' but recognised that the appellate authority is 'bound to test the decision against facts found by it at the date of the hearing' and in this sense comprises the judicial part of the decisionmaking process.

26. Sivakumaran v Secretary of State for the Home Department [1988] AC 958. The burden of proof in human rights claims under art 3 of the ECHR is expressed in different language - is there a real risk of ill-treatment contrary to art 3? - but has been held to be the same as that under the Refugee Convention: Kacaj v Secretary of State for the Home Department (starred determination) [2002] Imm AR 213; $R$ (Dhima) v Immigration Appeal Tribunal [2002] Imm AR 394.

27. Secretary of State for the Home Department $v$ RK (obligation to investigate) Democratic Republic of Congo [2004] UKIAT00129, para 46.

28. [2004] UKIAT00129, para 46.

29. The Franks Committee Report of the Committee on Administrative Tribunals and Enquiries (Cmnd 218, 1957) para 41.

30. $\mathrm{H}$ Genn and Y Genn The Effectiveness of Representation at Tribunals (London: Lord Chancellor's Department, 1989) p 3. 
presumed that tribunals, as court substitutes, ought to be informed by judicial values. A related criticism is that the values espoused by Franks reflected a preoccupation with the individual redress of grievance which ignored the collective and public interest in tribunal decision-making. In other words, Franks prioritised individualistic values such as openness, fairness and impartiality; it sidelined the importance of collective values such as efficiency and cost-effectiveness. ${ }^{31}$ This focus on individual redress is not surprising given that Franks considered that tribunals should be regarded as part of the machinery for adjudication and therefore an external control on administration. It is, however, arguably misplaced because tribunals undertake major social responsibilities, such as determining refugee claims, which are intimately connected with policy goals, such as maintaining immigration control, and therefore there is a strong governmental interest in the working and operation of tribunal systems. As tribunals can substitute their own decisions for that of the primary decision-maker, they are likely to be viewed within government as comprising part of the whole decision-making process for implementing policy. If so, then account needs to be taken of collective values when evaluating tribunal systems. Indeed, it has been argued that the failure to recognise that tribunals properly form part of the administration has inhibited both their growth and effectiveness. ${ }^{32}$

Despite the shortcomings of the Franks Report, the search for general criteria for evaluating tribunal systems is itself problematic because the concept of administrative justice itself is both elusive and transient. Much of the literature emphasises that administrative justice does not embody any fundamental or invariant principles against which decision-making systems can be evaluated; the principles and standards of administrative justice vary both with context and over time. ${ }^{33}$ It has, for instance, been argued that administrative justice should not be considered as a subject on its own but rather as a body of thought to be drawn upon in the design of a particular system. The values and standards of administrative justice exist only in the context of the substantive subject and the goals, policies and methods of the adjudicating body. ${ }^{34}$ In order to identify criteria for evaluating tribunal systems, it is perhaps therefore sensible to consider the experience of an individual system rather than seek to identify generally applicable standards. ${ }^{35}$

31. P McAuslan 'Administrative Law, Collective Consumption and Judicial Policy' (1983) 46 MLR 1; P Birkinshaw Grievances, Remedies and the State (London: Sweet \& Maxwell, 2nd edn, 1994) p 56.

32. J A Farmer Tribunals and Government (London: Weidenfeld and Nicolson, 1974) p 4.

33. See eg P Nonet Administrative Justice: Advocacy and Change in a Govermment Agency (New York: Russell Sage, 1969); M Partington 'Restructuring Administrative Justice? The Redress of Citizens' Grievances' (1999) 52 CLP 173 at 178-184; S Halliday Judicial Review and Compliance with Administrative Law (Oxford: Hart Publishing, 2004) pp 111-125. 34. T G Ison "'Administrative Justice": Is It Such a Good Idea?' in M Harris and M Partington (eds) Administrative Justice in the 21st Century (Oxford: Hart Publishing, 1999) pp 33-34.

35. For recent overviews of the administrative justice system as a whole, see Department for Constitutional Affairs, above n 3; National Audit Office Citizen Redress: What citizens can do if things go wrong with public services (HC 21, 2004-05). 
Suppose therefore that the government becomes responsible for processing a high volume of asylum applications (as has happened in the United Kingdom since the early 1990s). While initial decisions would be taken by front-line administrative staff to distinguish genuine and false claims, the establishment of an appeal process would enable refused claimants to challenge such decisions. One important aim of the appeal process would be to ensure that accurate decisions are reached through fair procedures. It would also be important to ensure that appeals are determined expeditiously to ensure that genuine claims are recognised and that unmeritorious applicants can be removed quickly. In view of the volume of appeals, a large number of immigration judges would be required but at the same time, it would be important to ensure that appeal decisions are sufficiently consistent. Furthermore, while the appeal process would operate in a sensitive political context, it would also need to be independent of the executive.

An adjudication process such as this would embody competing and conflicting values. In light of the consequences of adverse decisions to the claimant, the system would aim to produce accurate and consistent decisions by independent judges through fair procedures. At the same time, in view of the intense political scrutiny under which it operates, the system would have to be efficient, timely and final. Furthermore, government would have to translate these competing goals into operational reality, a task that, given limited financial and organisational resources, inevitably imposes its own restrictions. ${ }^{36}$

The asylum appeal system is then under pressure to fulfil a diverse and competing range of values. These competing values may be understood as reflecting different normative models - governmental and legal - of how decision-making processes should operate. ${ }^{37}$ In the governmental model, tribunals form part of the whole decision-making process, the purpose of which is to secure the most effective implementation of policy. Questions of the costeffectiveness, efficiency and timeliness of the tribunal process therefore assume critical importance. By comparison, the legal model views tribunals as part of the judicial system. Rather than focusing on the need to process the aggregate volume of appeals, the legal model prioritises the need to ensure the fair, correct and independent treatment of each individual case. From this perspective, tribunals should not allow the demands of efficiency and cost-effectiveness to take priority over the need for a fair, accurate and independent decision-making process.

A potential benefit of this approach is that it recognises the co-existence of competing perspectives concerning the nature and role of tribunal adjudication systems and the values which underpin their operation. As tribunals operate on the boundary between public administration and law, they cannot be understood solely by reference to a single model of how decision-making should be organised and conducted. In light of the ambivalent position of tribunal

36. For recognition of similar values in the social security context, see R Sainsbury 'Administrative Justice: Discretion and Procedure in Social Security Decision-Making' in K Hawkins (ed) The Uses of Discretion (Oxford: Oxford University Press, 1992) p 295. 37. See J L Mashaw Bureaucratic Justice: Managing Social Security Disability Claims (New Haven: Yale University Press, 1983) pp 24-31; D J Galligan Due Process and Fair Procedures: A Study of Administrative Procedures (Oxford: Oxford University Press, 1996) pp 237-240. 
systems - are they court substitutes or part of the administration? - the procedures they operate are likely to result from the tensions between the governmental and legal models of decision-making. However, this approach is not without its difficulties. First, there is a clear tension between the different values (eg fairness and timeliness) and different people may reasonably disagree as to the weight to be placed on competing values and how trade-offs between them should be struck. Secondly, while tribunals are informed by a range of competing values, it may be extremely difficult to assess with any degree of certainty the extent to which such values are fulfilled in any given decision-making system.

\section{ASSESSING ACCURACY ANDCONSISTENCY}

In seeking to evaluate the asylum appeals system, we might begin with the value of accuracy in decision-making, which, it has been argued, is the primary demand of any adjudicative system because irrespective of what other desirable qualities the decision-making process might possess, its decisions are unlikely to be acceptable if they are wrong. ${ }^{38}$ Ensuring decisional accuracy may be said to comprise three essential aspects: the collection of the correct facts concerning a claimant's situation; the correct interpretation of the relevant legal rule; and the appropriate application of the rule to the facts. Certainly in the asylum context, accuracy raises very serious considerations: an incorrect refusal decision may result in persecution, torture or even death while an incorrect decision to grant asylum will undermine the public interest in maintaining immigration control. In light of the legal-policy context of asylum adjudication, there is therefore a recognised public interest in ensuring accurate decision-making.

There are, however, several reasons why accuracy is an elusive concept. First, asylum adjudication is itself inherently problematic. As one immigration judge has explained, the superficial simplicity of asylum adjudication conceals 'a mass of detailed, difficult and very problematic factual and legal issues' ${ }^{39}$ If accurate decision-making requires the collection of facts and the application of the relevant legal rules to those facts, then ensuring accuracy in asylum adjudication is inherently difficult because the facts are often unclear and the legal relevant rules are embedded with discretion. To some extent, the adoption of the lower standard of proof compensates for the notorious difficulties applicants may experience in proving their claim as it allows for 'a more positive role for uncertainty' when the assessment of future risk is undertaken. ${ }^{40}$

However, claims necessarily have to be determined on the basis of incomplete, uncertain and contested evidence; applicants cannot usually call witnesses to support their claim. The consequence of this is that decision-makers frequently have to assess the credibility of the claimant's own evidence, an assessment which

38. Sainsbury, above $n 37, \mathrm{p} 302$.

39. C G Blake 'Judicial Review, Second Tier Tribunals and Legality' in M Partington (ed) The Leggatt Review of Tribunals: Academic Seminar Papers (Bristol: University of Bristol, Faculty of Law, 2001) pp 67, 68.

40. Kaja v Secretary of State for the Home Department [1995] Imm AR 1 at 8. 
may be heavily dependant on the decision-maker's own assumptions. For instance, it is not unreasonable to suppose that one immigration judge may consider an account by an asylum appellant to be incredible while another may accept it as wholly credible. As Sedley LJ recognised in Karanakaran, while decision-makers are required to take into account all material evidence when assessing risk of persecution, what they ultimately make of the material 'is a matter for their own conscientious judgment' ${ }^{41}$ An added complication is that in order to reduce the scope for abusive claimants making false claims in order to delay removal, the Asylum and Immigration (Treatment of Claimants, etc) Act 2004 imposes an obligation on decision-makers (including both IND officials and the tribunal system) to have regard to any behaviour on the part of a claimant which they believe is likely to mislead or conceal information or obstruct or delay the taking of a decision when assessing the individual's credibility. ${ }^{42}$ The risk, of course, is that genuine claimants may nevertheless be caught out by general presumptions concerning actions that undermine credibility. Asylum adjudication is, however, further complicated by the diversity of the clientele, the potential for cross-cultural misunderstandings and the difficulty of obtaining up-to-date and reliable information concerning conditions in countries producing asylum applicants. ${ }^{43}$

Further difficulties arise because of the uncertain reach of the eligibility criteria. As Laws LJ has noted, 'there are no sharp legal tests in this area' ${ }^{44}$ For instance, in order to determine whether removal would contravene art 3 of the ECHR, the Tribunal has distinguished between mere hardship and persecution or ill-treatment because 'it is simply not possible for this country to take in all who might suffer hardship' but has been unable to state how they are to be distinguished other than by identifying 'some particular reason in an individual case' which establishes that the treatment will contravene art $3 .^{45}$ Even where the facts are established and the law is clear, there can nevertheless be room

41. Karanakaran $v$ Secretary of State for the Home Department [2000] 3 All ER 449 at 479, per Sedley LJ.

42. Asylum and Immigration (Treatment of Claimants, etc) Act, 2004, s 8. See also the Immigration (Claimant's Credibility) Regulations 2004, SI 2004/3263.

43. For instance, the accuracy of the Home Office's Country Information reports is particularly contested: see Immigration Advisory Service Home Office Country Assessments: An Analysis (London: IAS, 2003). At the same time, the IAT has frequently expressed concerns that expert evidence regarding conditions in countries producing asylum applicants is not always wholly objective: see eg Slimani $v$ Secretary of State for the Home Department (starred determination) [2001] 01TH00092.

44. $N v$ Secretary of State for the Home Department [2004] ] WLR 1182 at 1201, per Laws LJ.

45. Secretary of State for the Home Department v Qosja [2002] UKIAT00756, para 8. See also Secretary of State for the Home Department $v$ SF (Article 3 -prison conditions) Iran $C G$ [2002] UKIAT00973. An appellant whose asylum and art 3 appeals have been dismissed may nevertheless argue that removal would contravene the right to family life under art 8; in such a case, the appellate authority must assess whether the case is so exceptional on its particular facts that the requirements of proportionality demand a decision in the appellant's favour notwithstanding that they do not qualify to remain under the Immigration Rules: see Huang, Abu-Qulbain and Kashmiriv Secretary of State for the Home Department [2005] EWCA Civ 105. 
for legitimate differences of opinion as to whether a claimant to refugee status has made good his claim'. ${ }^{46}$

Assessing the accuracy of decision-making output is no less problematic. It is, for instance, doubtful whether the rate of allowed appeals $-19 \%$ in $2004^{47}$ - is an adequate measure of the accuracy of initial decisions because appeals are not restricted to the identification of errors in the initial decision but are determined de novo in light of the facts in existence at the date of the hearing. As country conditions constantly change and appellants can advance new material as to whether or not they qualify as refugees, this inevitably means that new material is placed before the appellate authority that was not before the initial decision-maker. The consequence of this seems clear: it is often difficult to determine whether reversal on appeal is either an indication of error or merely the result of having an appeal process which frequently includes consideration of new evidence. Furthermore, the option of a de novo merits appeal can be problematic as the appeal process may itself introduce errors in decision-making, particularly in complex and factually uncertain areas such as asylum, which then have to be corrected either by an appeal tribunal or by way of judicial review thereby increasing the length and costs of the process.

One way of seeking to ameliorate the difficulties in achieving accurate decision-making is to pursue consistency. Like treatment of like cases ensures formal justice. However, consistency, like accuracy, is elusive. First, given the latitude open to decision-makers in the collection and weighing-up of evidence, it may be doubted whether consistent outcomes can be achieved when appeal hearings are determined individually by single immigration judges.

Secondly, it is precisely because accuracy is so elusive that ensuring greater consistency runs the risk of more inaccurate decision-making. An illustration of this risk is provided through the promulgation of country guideline (CG) determinations by the IAT. Country guideline determinations are intended to provide factually authoritative guidance on conditions in countries producing asylum applicants. ${ }^{48}$ For example, in $V L$, the IAT drew upon a range of country information in order to provide authoritative guidance on the risk of persecution to failed asylum-seekers on their return to the Democratic Republic of Congo. ${ }^{49}$ Such determinations are intended to be definitive and 'are expected

46. Saad, Diriye and Osorio v Secretary of State for the Home Department [2002] Imm AR 471 at 479, per Lord Philips MR.

47. The issue is complicated by the fact that the success rate on appeal differs by nationality. In 2003, eg, the highest success rate on appeal was 38\% for Sudanese and Somali nationals whereas the lowest success rate on appeal was $3 \%$ for Indian nationals. 48. The IAT's practice of promulgating country guideline determinations has been explicitly encouraged and endorsed by the higher courts in light of inconsistent IAT determinations assessing country conditions. See Manzeke $v$ Secretary of State for the Home Department [1997] Imm AR 524 at 529, per Lord Woolf MR; $S$ v Secretary of State for the Home Department [2002] INLR 416 at 435-436, per Laws LJ; Shirazi v Secretary of State for the Home Department [2004] 2 All ER 602 at 611, per Sedley LJ. For a critique of country guideline determinations, see Immigration Advisory Service Country Guideline cases: benign and practical? (London: IAS, 2005).

49. Secretary of State for the Home Department $v$ VL (risk - failed asylum-seekers) Democratic Republic of Congo CG [2004] UKIAT00007. As of April 2005, there were 299 current country guideline determinations. 
to be followed unless distinguishable by reference to individual circumstances or unless changes in conditions have occurred'. ${ }^{50}$ As the IAT has explained, the production of country guidance is an important part of its function, 'enabling the parties to know where they stand and assisting the achievement of consistent decision-making' ${ }^{51}$ The Tribunal has then promulgated a considerable number of country guideline determinations the purpose of which is to "lay down an approach to a settled factual situation, not to decree that that situation is to be treated as if it were the same for ever' ${ }^{52}$

The production of country guideline determinations is not, however, without its own difficulties. First, there are the problems associated with the availability of sufficient and up-to-date material concerning country conditions in order to provide an effectively comprehensive country guideline determination. Secondly, it is apparent that different inferences concerning the risk of persecution may be drawn from the same country materials. As the Tribunal has itself recognised, 'it is perfectly possible for differing views reasonably to be held about the same country conditions but it would be wholly unreasonable ... for there to be a divergence of practice in relation to essentially similar cases'. ${ }^{53}$ By contrast, Good has criticised the Tribunal for its naive empiricism in accepting at face value that it is possible to construct 'objective evidence' with regard to country conditions that is not already grounded in some background theory or interpretative approach and for failing to recognise that 'truth' is at best provisional and contested. ${ }^{54}$ The task of reaching accurate decisions concerning the conditions in countries generating asylum applicants is then inherently problematic because asylum decision-making is an interpretive and evaluative exercise for which there are no objective standards. Innovations such as country guideline determinations might promote consistency in decision-making but if a country guideline determination is inaccurate, then there is a risk of that inaccuracy being compounded in subsequent appeals.

\section{APPEAL PROCEDURES}

If accuracy is so elusive and consistency runs the risk of greater inaccuracy, how then can the appeal system be evaluated? One approach might be to

50. FS v Secretary of State for the Home Department (Iran-Christian converts) Iran $C G$ [2004] UKIAT00303, para 6.

51. DK $v$ Secretary of State for the Home Department (return-ethic Serb-upheld SK - accommodation) Croatia CG [2003] UKIAT00153, para 8.

52. LT v Secretary of State for the Home Department (internal flight - registration system) Turkey CG [2004] UKIAT00175, para 3.

53. Secretary of State for the Home Department $v B D$ (application of SK and DK) Croatia $C G$ (starred determination) [2004] Imm AR 226 at 244.

54. A Good "'Undoubtedly An Expert"? Anthropologists in British Asylum Courts' (2004) 10 Journal of the Royal Anthropology Institute 113; A Good 'Expert Evidence in Asylum and Human Rights Appeals: an Expert's View' (2004) 16 IJRL 358. In response, the Tribunal has questioned whether the reports of many country experts are objective and impartial: see J Barnes 'Expert Evidence - The Judicial Perception in Asylum and Human Rights Appeals' (2004) 16 IJRL 349. 
examine the decision-making process itself, the fact-gathering routines adopted and onward appeal rights. After all, the function of the process is to determine claims; the procedures used to determine appeals and the actual substantive outcomes reached are inseparable. The fairness and independence of the process are likely to exert significant influence on the accuracy of decision-making. Procedures are, however, also conditioned by other values such as cost, timeliness and efficiency.

When the immigration appeal system was initially established it was intended to be informal and largely inquisitorial, and legal representation was not envisaged as necessary. However, various pressures - the increasing number of appeals, the complexity of the law, control by the higher courts - created pressures for the judicialisation of the procedure. ${ }^{55}$ As a consequence, the basic fact-gathering routine of asylum appeals has largely been predicated on the legal model of decision-making in which hearings are adversarial contests with both sides appearing with representation, the appellant delivers oral evidence and is cross-examined. Furthermore, in order to remain neutral and impartial, the adjudicator must not descend into the arena by intervening during the appeal hearing. ${ }^{56}$ The position of asylum appeals is not, however, without some difficulty. Although the appeal system has drawn upon a legal model of decision-making, immigration and asylum appeals are excluded from the scope of the right to a fair trial under art 6 of the ECHR as decisions governing entry into a state concern public law rights rather than private law rights. ${ }^{57}$ Nevertheless, the exclusion of asylum decisions from art 6 will make little difference if there is an independent and fair appeal process.

While the appeal process has come to operate in accordance with a legal model of decision-making processes, it has, however, increasingly been put under pressure to meet the demands of efficiency and cost-effectiveness. In other words, to prioritise the values which inhere in the governmental model of decision-making. Many of the problematic issues within the appeal system have arisen because of this tension. For instance, the appeal procedural rules stipulate tight time limits for the submission and determination of appeals. ${ }^{58}$ The Department for Constitutional Affairs and the Home Office have agreed joint targets for processing volumes of appeals within agreed time-frames. ${ }^{59}$

55. D Pearl 'Immigration and Asylum Appeals and Administrative Justice' in Harris and Partington (eds), above $\mathrm{n} 35, \mathrm{p} 55$.

56. As the IAT explained in Oyono $v$ Secretary of State for the Home Department [2002] UKIAT02034, para 8: '[a]n adjudicator who intervenes during the course of evidence is running the risk that he will be seen to be taking the side of one party or the other.' $\mathrm{Cf}$ L L Fuller 'The Forms and Limits of Adjudication' (1978) 92 Harv LR 353 at 382-384. 57. Maaouia v France (2001) 33 EHRR 42; MNM v Secretary of State for the Home Department (starred determination) [2000] INLR 576; AMv Secretary of State for the Home Department ('upgrade' appeals: Art 6?) Afghanistan (starred determination) [2004] Imm AR 530.

58. See Department for Constitutional Affairs Asylum and Immigration Tribunal Procedure Rules, and Judicial Titles Order Consultation Paper 27/04 (London: DCA, 2004); Asylum and Immigration Tribunal (Procedure) Rules 2005, SI 2005/230.

59. According to the Department for Constitutional Affairs Departmental Report 2003/ 04 (Cm 6210,2004) para 2.89, the DCA shares a joint target with the Home Office to ensure that $60 \%$ of new substantive asylum applications are decided (including final appeal) within six months. 
The IAA has become imbued with a managerial culture in which immigration judges sit on a ' $1+1$ ' sitting pattern in which they hear three asylum appeals one day and are expected to write their determinations the next.

In order to reduce the spiralling costs of publicly funded representation, the government in 2004 introduced restrictions under which representation at initial interviews will not generally be publicly funded and representation for appeals will only be publicly funded with prior approval from the Legal Services Commission and then only within financial thresholds. ${ }^{60}$ While empirical research indicates that appellants benefit from representation, such restrictions create disincentives for quality practitioners to remain within the jurisdiction and also raises the possibility of more unrepresented appellants. ${ }^{61}$ In light of the factual and legal complexity of many appeals, the inability of many appellants to represent themselves, the seriousness of the outcome of appeals and, for many applicants, the lack of a privately funded option, such restrictions may adversely impact on the quality of the appeal process. The discomfort engendered by these restrictions can be seen reflected in the recent ruling of the Court of Appeal in Dirshe where it was held that the presence of a representative at an asylum interview provided a real, practical safeguard against faulty interpreting or inadequate and inaccurate record-keeping by the Home Office; in the absence of such a safeguard, it would be unfair for interviews not to be tape-recorded. ${ }^{62}$

The emphasis on speed is even more focused in fast-track appeal processes which supplement the normal appeal process. For instance, applicants whose claims are considered to be straightforward may be detained and processed through a tight timetable. ${ }^{63}$ Furthermore, since 2002 asylum applicants from designated safe countries whose claims are considered by the Home Office to be clearly unfounded may only appeal from outside the United Kingdom. ${ }^{64}$

60. 415 HC Official Report (6th series) cols 34-37WS, 27 November 2003; Community Legal Service (Scope) Regulations 2004, SI 2004/1055. See also House of Commons Constitutional Affairs Committee Fourth Report: Immigration and Asylum: the Government's proposed changes to publicly funded immigration and asylum work (HC $1171,2002-03)$.

61. See Asylum Aid and Bail for Immigration Detainees Justice Denied: Asylum and Immigration Legal Aid - A System in Crisis (London: BLD, 2005). For empirical evidence concerning the importance of representation for tribunal appellants, see Genn and Genn, above $\mathrm{n} 31$.

62. $R$ (Dirshe) v Secretary of State for the Home Department [2005] EWCA Civ 421. In $R$ (Mapah) v Secretary of State for the Home Department [2003] Imm AR 395 the High Court had previously held that the refusal to tape-record interviews was not unfair. In the view of the Court of Appeal in Dirshe, the recent restrictions on publicly funded representation made this continuing refusal procedurally unfair.

63. See Immigration and Asylum Appeals (Fast Track Procedure) Rules 2003, SI 2003/ 801 , under which refused claimants have two days in which to appeal as opposed to normal ten days. The legality of this scheme was upheld by the Court of Appeal in $R$ (Refugee Legal Centre) $v$ Secretary of State for the Home Department [2004] EWCA Civ 1481 , which held that the process was not unfair so long as it operated flexibly. See now Asylum and Immigration (Fast Track Procedure) Rules 2005, SI 2005/560.

64. Nationality, Immigration and Asylum Act 2002, s 94 . Applicants whose claims have been certified as clearly unfounded may challenge the legality of the certificate by way of judicial review, see $Z L$ and VL $v$ Secretary of State for the Home Department [2003] 
Such 'non-suspensive appeals' have been justified by the Home Office on the basis that they reduce the burden imposed by asylum applicants (ie support and accommodation costs) who arrive from countries generally considered to be safe and discourage potential unmeritorious applicants. From a legal perspective, however, the consequence of such appeals is bizarre: claimants refused initially by the Home Office may only appeal after the implementation of the decision whose validity the appeal is intended to test. As appellants in such cases are only able to appeal from outside the country and not therefore attend any appeal hearing, the utility of this appeal mechanism would appear to be highly limited.

Other features of the system may impinge upon the operational independence of the appeal process. ${ }^{65}$ One long-standing concern has been the requirement that an appellant lodge the notice of appeal with the Home Office rather than the appellate authority with the consequence that ' $[t]$ he speed at which the appeal proceeds ... is entirely in the hands of the Home Office'. ${ }^{66}$ Under the new procedure rules, appeal notices will be lodged directly with the Tribunal. At the same time, however, the new rules also stipulate that the Tribunal must send its determinations in asylum appeals directly to the Home Office which will then serve the determination on the appellant. ${ }^{67}$ While this process may assist the Home Office in ensuring that unsuccessful appellants do not abscond, it may also undermine the perceived independence of the appellate authority.

It would, however, be mistaken to assume that the activities of the Home Office exemplify efficient policy implementation for the following reasons. First, primary decision-making has often been criticised for being of indifferent quality, poorly reasoned, inadequately engaging with the evidence of the applicant and for disclosing factual errors concerning country conditions. The Tribunal has, for instance, criticised the 'apparently cursory approach which appears to have been taken ... in the initial decision-making exercise ... the lack of skilled and professional care in reaching the initial decision necessarily places extra burdens on adjudicators' ${ }^{68}$ As the National Audit Office has noted:

Imm AR 330; Atkinson v Secretary of State for the Home Department [2004] EWCA Civ 846. In $R$ (Husan) v Secretary of State for the Home Department [2005] EWHC Admin 189, the Administrative Court declared unlawful the designation of Bangladesh as a country in which there is in general no serious risk of persecution. The Asylum and Immigration (Treatment of Claimants, etc) Act 2004, s 27 enables the Home Office to expand considerably the scope of non-suspensive appeals.

65. In 1987, responsibility for appointing adjudicators was transferred from the Home Office to (what is now) the Department for Constitutional Affairs. IAT members have always been appointed by the Lord Chancellor since the inception of the appeal system in 1969 .

66. C G Blake 'Immigration Appeals - The Need for Reform' in A Dummett (ed) Towards a Just Immigration Policy (London: Cobden Trust, 1986) p 179. This procedure has proved particularly useful to the Home Office when it has sought to delay the determination of claims from a specific country until the conditions have improved. A specific example is provided by the Chief Adjudicator's decision to accede to a request by the Secretary of State to adjourn all Iraqi asylum appeals on the outbreak of the Iraq war in 2003. See further M Quayum and M Chatwin 'A fair-handed approach?' (2003) 153 NLJ 533.

67. Asylum and Immigration Tribunal (Procedure) Rules 2005, SI 2005/230, r 23(4).

68. Honvath $v$ Secretary of State for the Home Department [1999] Imm AR 121 at 129-130. 
'[p]ressure to meet processing targets, the complexity of some cases and a lack of clear ownership within the process for decisions once the case is passed onto the next stage sometimes lead to issues having to be resolved unnecessarily at the appeal stage.' ${ }^{69}$ The processing of initial claims has also been hampered by numerous administrative difficulties within IND, an organisation whose culture is, perhaps owing to the very nature of the tasks it exists to undertake, characterised by a 'tyranny of case-work and short-term crisis management' ${ }^{70}$ By way of example of the quality of Home Office administration, there is the practice by which the Home Office publishes an extra-statutory concessionary policy to allow certain classes of applicant to remain in the country but then refuses applications without reference to the policy leading to further challenges. ${ }^{71}$ Furthermore, the reluctance of the Home Office to establish an effective feedback process from the appeal system to improve initial decisionmaking standards is an important omission; as the National Audit Office has noted, 'significant costs are incurred in adjudicators addressing weaknesses arising at the front-end of the process'. ${ }^{2}$ While the Home Office has recently introduced its own rudimentary internal arrangements to assess the quality of primary decision-making, these monitoring systems could nevertheless be significantly expanded. ${ }^{73}$

Secondly, there has been the frequent non-attendance of Home Office presenting officers at appeal hearings. In the year up to August 2003, presenting officers only attended $72 \%$ of appeal hearings. ${ }^{74}$ As the Tribunal has noted:

69. National Audit Office, above $n 7, \mathrm{p} 7$.

70. PHennessy Whitehall (London: Pimlico, rev edn, 2001) p 460. For example, the decision to introduce a large-scale computer system to improve decision-making, which failed to materialise, led to the reduction of 1,200 staff. According to the House of Commons Public Administration Committee Third Report: Ombudsman Issues (HC 448, 2002-03) para 29: "the decision to get rid of experienced caseworkers before a system was in place verges on administrative negligence. In the current political atmosphere surrounding the question of asylum such mistakes can have especially unhappy consequences.' Regrettably, these problems were compounded by the sudden inflow of asylum claims with the Kosovan crisis in 1999. The upshot of this was an increase in the length of the backlog of asylum claims, which peaked at 125,000 in early 2000 , resulting in long delays in the processing of individual claims and the complete incapacity of the agency to manage asylum. The resultant situation was recognised by the government itself to be a 'catastrophe' and having to deal with it was akin to 'trying to turn round a supertanker with a ship that was actually sinking' (House of Commons Home Affairs Committee Second Report: Asylum Applications (HC 218-II, 2003-04) Ev 5 (Bev Hughes MP)).

71. In Secretary of State for the Home Department v Abdi [1996] Imm AR 148 the Court of Appeal held that a decision may not be in accordance with the law if taken in ignorance of an extra-statutory policy and that the appellate authority should in such circumstances remit the matter back to the Home Office. See eg Secretary of State for the Home Department v KK (under 12 policy - in country implications) Jamaica [2004] UKIAT00268; TG v Secrefary of State for the Home Department (considering policies) Nigeria [2005] UKIAT00024. In a recent decision, the Administrative Court held that the failure to apply a concessionary policy could breach an individual's legitimate expectations: see $R$ (Rashid) $v$ Secretany of State for the Home Department [2004] EWHC Admin 2465 .

72. National Audit Office, above n 7, p 7 .

73. National Audit Office, above n 7, pp 41-42, 45.

74. 416 HC Official Report (6th series) col 981 w, 19 January 2004. 
'[i]n what is essentially an accusatorial system, the ... [immigration judge] ... is all too frequently placed in a near impossible situation in avoiding descending into the arena and on the other hand wishing to have the evidence properly tested in order for proper findings of fact to be made. ${ }^{75}$ An immigration judge cannot be expected to conduct the case for the Home Office as this will undermine his impartiality; at the same time, it is important that the claimant's evidence is properly tested and all the relevant evidence material to ensure that a correct decision is arrived at. In the absence of a presenting officer, there is an increased risk that some appeals are allowed without the Home Office's case being fully considered. While recognising that the problem of nonattendance has been caused by the increasing volume of appeals, the Tribunal has criticised the Home Office for its 'now notorious inefficiency' in allowing appeals to proceed without presenting officers: '[i]t is as if in a criminal case the Crown were unrepresented. ${ }^{76}$ In response to this problem the Tribunal issued 'the Surendran guidelines' which enable immigration judges to raise issues of their own volition at the appeal hearing, though for the purpose of clarification only. ${ }^{77}$ When the Home Office does attend, the IAT has nevertheless been highly critical of its handling and presentation of appeals. ${ }^{78}$ The Tribunal has, for instance, criticised Home Office attempts to challenge adjudicators' determinations in favour of the appellants where the Home Office itself was not represented at the appeal hearing on the basis that the adjudicator failed to follow the Surendran guidelines or to make sound credibility findings. ${ }^{79}$

75. Secretary of State for the Home Department v IA HC KD RO HG (risk-guidelines -55eparatist) Turkey CG [2003] UKIAT00034, para 46.

76. $M v$ Secretary of State for the Home Department (Chad) [2004] UKIAT00044, para 4; MNM v Secretary of State for the Home Department (starred determination) [2000] INLR 576 at 582.

77. Surendran v Secretary of State for the Home Department [1999] (21679).

78. In Secretary of State for the Home Department v Tatar [2000] 00TH01914, paras 3-4, a Tribunal panel chaired by the then President Collins J, after detailing routine Home Office handling of appeals - 'files are not provided, documents are not available, they do not put it evidence that they ought to put in, they fail totally to produce any skeleton arguments, the list goes on and on and the Tribunal is simply getting fed up with it' concluded that the Home Office does 'not seem capable of dealing with the appeals in the manner in which they ought to be dealt with. The result is that the Tribunal is left in an impossible position'. In Secretary of State for the Home Department v Razi [2001] 01TH01836, paras 16-17 the Tribunal simply stated that 'it is hard to imagine any other department of state in this country where such incompetence would be tolerated' but further noted that the Home Office's failings were so severe that it 'begins to go beyond mere institutional incompetence, into the realm of an institutional culture of disregard for adjudicators, who are the primary judicial authority in this country for making sure that immigration powers are efficiently, as well as fairly exercised'. In Benkaddouri $v$ Secretary of State for the Home Department [2004] INLR 1 at 3 there had been 'a disgraceful series of errors and omissions, verging on the contumacious, on the part of the Home Office'. 79. Beteringhe v Secretary of State for the Home Department [1999] 18120; Secretary of State for the Home Department v Gjurgjei, Hoxha and Mersin [2001] 01TH00197; Secretary of State for the Home Department v Shafiei [2002] UKIAT05409. 
Thirdly, while the Home Office has frequently complained that many challenges by asylum appellants are vexatious and abusive attempts to prolong their stay in the country by stringing out endless appeals, the Home Office has itself been responsible for a substantial amount of the delays in the decisionmaking process. In recent years, the attention of both the IAT and the higher courts has been focused on claims brought by asylum applicants who have waited months and sometimes years for an initial decision from the Home Office, become established in the United Kingdom and challenge removal under the right to private and family life under art 8 of the ECHR. For example, in Shala the Court of Appeal held that when the Home Office had delayed for four years in determining an individual's asylum claim, which would have been granted had it been decided in an appropriate timescale, it could not then insist that the same individual return to his country of origin to apply to enter the United Kingdom in order to continue his family life which he had established in the meantime, as this would have been both unjust and a disproportionate interference with the right to family life. ${ }^{80}$ This is not to imply that there are not abusive challenges by failed appellants - the courts, for instance, have become more vocal in their criticism of unmeritorious challenges ${ }^{81}$ - but to stress that the Home Office itself has been responsible for substantial delays in the decision-making process.

A further obstacle to the operation of an effective appeal process arises from the standard of representation which is, according to the Council of Immigration Judges, 'very variable in quality' ${ }^{82}$ There are certainly a substantial number of representatives who provide high-quality services and many are members of organisations that are key players in the broader asylum debate. At the same time, there are those who provide either incompetent, unscrupulous or exploitative services; while good representation may assist the appeal process,

80. Shala $v$ Secretary of State for the Home Department [2003] INLR 349. This is not an isolated example. In Secretary of State for the Home Department $v$ Wachai [2002] UKIATO6682, the IAT rejected a Home Office appeal against allowing a family to remain under art 8 in light of the unexplained delay in reaching a decision: '... the Home Office cannot now be allowed to excuse their own inaction, in taking such inexplicably slow steps over the years to decide the future of a family with young children, in terms of the legitimate purpose of maintaining an effective system of immigration control, which they themselves so signally failed to secure.' Subsequent cases have emphasised that Shala depended on its own unusual set of facts and was not intended as a general encouragement to the appellate authorities to compensate for delays by the Home Office: see $D M v$ Secretary of State for the Home Department (proportionality-Article 8) Croatia (starred determination) [2004] Imm AR 211; Janjanin and Musanovic $v$ Secretary of State for the Home Department [2004] Imm AR 264.

81. See eg Dahmani $v$ Secretary of State for the Home Department [2003] Imm AR 479; $R$ (nine Nepalese asylum seekers) v Immigration Appeal Tribunal [2003] EWCA Civ 1892. In $R$ (Pharis) v Secretary of State for the Home Department [2004] 3 All ER 310 at 313 Brooke $\mathrm{LJ}$ stated that: '[e]xperience has shown that the practice of pursuing a further appeal to this court in a judicial review matter in the immigration and asylum field has given rise to very serious abuse, with appellants pursuing wholly unmeritorious appeals simply to delay the time when they are to be deported.'

82. House of Commons Constitutional Affairs Committee Second Report: Asylum and Immigration Appeals (HC 211-11, 2003-04) Ev 200. 
bad representation may positively hinder it. ${ }^{83}$ As the Tribunal has stated: "the standard of preparation and advocacy of those appearing on behalf of the appellants before Adjudicators (and occasionally the Tribunal) is not uniformly high. ${ }^{84}$ While the government has taken active steps to raise standards, for instance, by regulating the non-professional sector, recent restrictions on publicly funded immigration casework through the introduction of financial thresholds for the preparation of appeals has created disincentives for good quality providers and the possibility of more unrepresented appellants. ${ }^{85}$

The difficulties in maintaining adversarial procedures - poor representation, non-attendance by the Home Office and the possibility of more unrepresented appellants - has raised the question whether immigration judges should adopt a more interventionist approach in appeal hearings. It has been argued that such an approach is a more appropriate means of applying the refugee tests and the lower standard of proof ${ }^{86}$ Hathaway, for instance, has explained that the peculiar difficulties of asylum adjudication demand more than traditional, passive adjudication. ${ }^{87}$ More broadly, the Leggatt Report recommended that tribunals adopt an 'enabling' approach in which the tribunal supports the parties in ways which give them confidence to participate in the process and also compensates for the appellant's lack of skills or knowledge. ${ }^{88}$ However, the adoption of such an approach requires considerable skill on the behalf of immigration judges to elicit the necessary facts while remaining impartial. It also runs the risk of replacing a confrontational adversarial approach with an accusatory style of inquisition. To

83. In 1998, the Lord Chancellor's Advisory Committee on Legal Education and Conduct Improving the Quality of Immigration Advice and Representation: A Report (1998) para 2.32 noted that ' $[\mathrm{t}]$ here is considerable concern within the Immigration Appellate Authorities and many immigration advice agencies about the quality of representation at immigration appeals and, especially, asylum appeals.' A recurrent problem has been that of discontinuous representation whereby different representatives will provide initial advice and assistance to those who represent claimants at the appeal hearing.

84. IS v Secretary of State for the Home Department (concession made by representative) Sierra Leone [2005] UKIAT00009, para 15. In Devaseelan v Secretary of State for the Home Department (starred determination) [2003] Imm AR 1 at 14 the Tribunal noted: 'an increasing tendency to suggest that unfavourable decisions by Adjudicators are brought about by error or incompetence on the part of representatives. New representatives blame old representatives, sometimes representatives blame themselves for prolonging the litigation by their inadequacy (without, of course, offering the public any compensation for the wrong that from which they have profited by fees).'

85. The Immigration and Asylum Act 1999, s 83(3) established the Office of the Immigration Services Commissioner 'to promote good practice by those who provide immigration advice or immigration services'. The Asylum and Immigration (Treatment of Claimants, etc) Act 2004, ss 37-41 strengthens the powers of the Immigration Services Commissioner.

86. S Kneebone 'The Refugee Review Tribunal and the Assessment of Credibility: an Inquisitorial Role?' (1998) 5 Australian Journal of Administrative Law 78.

87. J Hathaway Rebuilding Trust - Report of the Review of Fundamental Justice in Information Gathering and Dissemination at the Immigration and Refugee Board of Canada (1993) p 6.

88. Leggatt, above n 3, paras.7.2-7.6. Such an approach is more accurately described as 'interventionist' or 'enabling' rather than 'inquisitorial' as this assumes that the tribunal takes full control of the proceedings. See C Harlow 'The ECHR and Administrative Justice' in Partington (ed), above n 40, pp 52-53. 
some extent, the IAT has sought to resile from its strict insistence on adversarial procedures by stating that adjudicators are not limited to intervening during evidence solely for clarification purposes: they may intervene in order for the purpose of the general control of a case and to raise any inconsistency in the claimant's evidence provided it is done in a fair and non-hostile manner. ${ }^{89}$ The IAT has justified this development by reference to the clear differentiation between asylum adjudication and ordinary civil litigation and the important public interest in ensuring claims are subject to anxious scrutiny. ${ }^{90}$ However, the move towards a more enabling approach has not been unproblematic. In relation to appeals not attended by the Home Office, the Tribunal has noted that the tension implicit in the Surendran guidelines - the adjudicator must ensure that the unrepresented appellant is aware of those points which may lead to an adverse conclusion but also must not appear to be partisan by asking questions no one else has thought necessary to ask - 'has proved troublesome on a number of occasions' ${ }^{91}$ Moreover, it has been doubted whether this approach is able adequately to compensate for the lack of effective representation. ${ }^{92}$

\section{REFORMING THE APPEAL STRUCTURE: ONWARD APPEAL RIGHTS}

Given the difficulties experienced at the initial appeal level, the existence and operation of onward appeal rights assume particular importance. As Table 2 indicates, a growing volume of appeals have been determined by the IAT in recent years. It is in this respect that the 2004 Act will impact as the established two-tier structure of appeals will be replaced by the new single-tier AIT. However, before examining the possible impacts of this reform, attention might be focused on the role and function of second-tier appellate tribunals and the operation of the IAT.

89. $K v$ Secretary of State for the Home Department (Côte d'Ivoire) [2004] UKIAT00061, paras 42-45.

90. $M v$ Secretary of State for the Home Department (Chad) [2004] UKIAT00044, para 16; Secretary of State for the Home Department v $L K$ (adjudicators: 'anxious scrutiny' - public interest) Democratic Republic of Congo [2004] UKIAT00308, para 7.

91. WN v Secretary of State for the Home Department (Surendran-credibility-new evidence) Democratic Republic of Congo [2004] UKIAT00213, para 39. See also SW v Secretary of State for the Home Department (adjudicator's questions) Somalia [2005] UKIAT00037.

92. H Genn 'Tribunals and Informal Justice' (1993) 56 MLR 393. 
Table 2: IAT asylum appeals 2000-04 $4^{93}$

\begin{tabular}{|l|l|l|l|l|l|}
\hline & 2000 & $\mathbf{2 0 0 1}$ & $\mathbf{2 0 0 2}$ & $\mathbf{2 0 0 3}$ & $\mathbf{2 0 0 4}$ \\
\hline $\begin{array}{l}\text { Appeals } \\
\text { determined by } \\
\text { IAA Adjudicators }\end{array}$ & 19,395 & 43,415 & 64,405 & 81,725 & 55,975 \\
\hline $\begin{array}{l}\text { Appeals allowed } \\
\text { (success rate \%) }\end{array}$ & $\begin{array}{l}3,340 \\
(17 \%)\end{array}$ & $\begin{array}{l}8,155 \\
(19 \%)\end{array}$ & $\begin{array}{l}13,875 \\
(22 \%)\end{array}$ & $\begin{array}{l}16,070 \\
(20 \%)\end{array}$ & $\begin{array}{l}10,845 \\
(19 \%)\end{array}$ \\
\hline $\begin{array}{l}\text { Applications for } \\
\text { permission to } \\
\text { appeal to the IAT }\end{array}$ & 6,020 & 15,540 & 25,600 & 34,955 & 29,265 \\
\hline $\begin{array}{l}\text { IAT appeals } \\
\text { determined }\end{array}$ & 2,635 & 3,190 & 5,565 & 9,450 & 8,785 \\
\hline Appeals allowed & 815 & 475 & 620 & 1,490 & 1,060 \\
\hline $\begin{array}{l}\text { Appellant } \\
\text { successful }\end{array}$ & 650 & 315 & 410 & 535 & 300 \\
\hline $\begin{array}{l}\text { Secretary of } \\
\text { State successful }\end{array}$ & 170 & 160 & 215 & 955 & 760 \\
\hline $\begin{array}{l}\text { Appeals } \\
\text { dismissed }\end{array}$ & 1,385 & 1,140 & 2,015 & 3,230 & 2,965 \\
\hline $\begin{array}{l}\text { Appeals remitted } \\
\text { back to the IAA }\end{array}$ & 215 & 1,430 & 2,700 & 4,220 & 3,915 \\
\hline
\end{tabular}

What is the rationale of second-tier appellate tribunals? First, appellate tribunals seek to combine expertise with oversight of initial appeal determinations. As a specialist appellate tribunal, the IAT, for instance, has sought to identify current trends and problems, provide guidance to adjudicators and settle important points of law to ensure consistency on the behalf of adjudicators. Secondly, second-tier appeal tribunals determine substantive appeals against first-tier appeal decisions. While this is an important function is its own right, it should be noted that the scope of an appellate jurisdiction can be controversial. An appeal tribunal can provide a useful check on first instance appeal decision-making. However, if the appeal tribunal adopts too expansive an approach to its own jurisdiction, then it runs the risk of undertaking a rerun of the first instance appeal and inviting speculative challenges against firsttier appeal decisions.

At the same time, second-tier tribunals may impose additional costs and delays on the decision-making process. The volume of onwards appeals to the IAT in asylum appeals has been considerable in a jurisdiction marked by its culture of challenge. These appeals inevitably increase costs as applicants are supported throughout the process and delay removal action. In 1998, the government expressed concern that the IAT made too many inconsistent decisions, its decisions were too frequently overturned by the Court of Appeal,

93. Home Office Asylum Statistics 2000-2004. These figures exclude dependants. The number of initial decisions and appeals in a particular year do not necessarily relate to the claims lodged in the same year. 
there were too many remittals back to adjudicators and too many judicial review claims against IAT decisions refusing permission to appeal. ${ }^{94}$ Despite these concerns, the government recognised the need for an enhanced second-tier appellate tribunal until it decided in 2003 to move to a single tier of appeal. ${ }^{95}$

How then has the IAT discharged its functions? The IAT has sought to ensure consistency on points of law by promulgating 'starred determinations', which are determined by a specially convened legal panel and which 'must therefore be followed by all tribunals and will be regarded as binding upon all adjudicators' unless they are inconsistent with higher authority binding on the appellate authorities. ${ }^{96}$ Country guideline determinations have provided a useful albeit controversial means of ensuring consistency in relation to conditions in countries of origin. Furthermore, by determining a considerable volume of permission to appeal applications, IAT members have been able to identify current trends and issue guidance to adjudicators. ${ }^{97}$

It has perhaps been in relation to its role of determining individual appeals that the IAT has encountered difficulties which have at least in part contributed to its abolition. First, there has been the volume of appeals remitted by the IAT back to adjudicators for determination. In 2003, $44 \%$ of IAT appeals were remitted back to adjudicators for further consideration because of a defect in the adjudicator's determination with the consequence that the length of the process is increased and new appeals are pushed back. ${ }^{98}$ The IAT would remit an appeal if the adjudicator's determination was flawed by reason of a procedural or other error, such as a failure to make proper findings of fact, which the Tribunal could not itself correct. Such a high rate of remittals might be explicable by reference to the intense pressure on adjudicators who during 2003-04 had to hear three appeals in each hearing day and might not have sufficient time to write a well-reasoned determination. Other explanations might include: the complexity of much of the law governing asylum and human rights appeals; the fact that a majority of adjudicators work part-time; and, finally, the fact that '[t]he quality ... [of adjudicators] ... is not altogether even'. ${ }^{99}$

Secondly, the jurisdiction of the IAT's jurisdiction has been subject to statutory change and the scope of this jurisdiction has been uncertain. Under the $1999 \mathrm{Act}$, the IAT's jurisdiction was to determine appeals against

94. Home Office and Lord Chancellor's Department Review of Appeals: A Consultation Paper (London: Home Office and LCD, 1998) paras 5.3-5.4.

95. For instance, in its 1998 and 2002 White Papers Fairer, Faster and Firmer - A Modern Approach to Immigration and Asylum (Cm 4018, 1998) para 7.18 and Secure Borders, Safe Haven: Integration with Diversity in Modern Britain (Cm 5387, 2002) para 4.66, the Home Office affirmed the need for an enhanced IAT.

96. Ali Haddad $v$ Secretary of State for the Home Department (starred determination) [2000] INLR 117 at 118. As of April 2005, the IAT had promulgated 39 starred determinations since the introduction of the starring system in 2000 .

97. In 2004, the IAT was composed of a President, Deputy-President, 26 full-time VicePresidents, 50 part-time legally qualified Chairpersons and 60 lay members. In 2003-04, IAT Vice-Presidents spent one week in four determining 120 applications for permission to appeal.

98. Home Office Asylum Statistics 2003, Table 7.2.

99. According to Sir Andrew Collins in oral evidence before the Constitutional Affairs Committee, above n 83, Ev 33. 
adjudicators' determinations on both fact and law. ${ }^{100}$ Given the public interest in achieving finality in litigation, the Court of Appeal held that appeals to the IAT should only succeed not merely where the IAT would have preferred a different view from that of the adjudicator but where it is required by objective evidence to adopt a different view. ${ }^{101}$ Under the 2002 Act, the IAT's jurisdiction was limited to determining appeals solely on the basis of a point of law (see above Figure 1); up-to-date evidence of personal or country circumstances would not be admissible in a substantive appeal unless if it was first demonstrated that there was a material error of law in the impugned decision. ${ }^{102}$ Though the IAT's jurisdiction has been so confined, the exercise of that jurisdiction has at times proved controversial: the IAT has been criticised by the Court of Appeal for interfering too readily with adjudicators' determinations and for not confining itself to its proper reviewing role especially when the IAT has allowed Home Office appeals against first instance appeals in favour of asylum applicants. ${ }^{103}$ In Arshad, for example, Laws LJ expressed anxiety that the IAT's determination in favour of the Home Office portrayed 'a (no doubt unconscious) lack of even-handedness on the part of the IAT as between an immigrant's appeal and a Home Office appeal'. ${ }^{104}$ More recently, the Court of Appeal, restoring the decisions of two adjudicators allowing appeals, stated that: 'it is important that the IAT confines itself to its proper reviewing role, because there is justified concern at the length of the appeal process. This has contributed to Parliament changing the process in a way that will restrict the rights of the parties to appeal.' ${ }^{\text {los }}$

A further source of controversy has concerned routes of challenge against the IAT's refusal of permission to appeal. Unlike other tribunal jurisdictions, the asylum appeal system has been unable to prevent further challenges to tribunal decision-making by way of judicial review. The source of the problem has been that IAT's refusal of permission to appeal could be challenged by way of judicial review, which has in recent years comprised a substantial

100. Immigration and Asylum Act 1999, Sch 4, para 22.

101. Subesh, Suthan, Nagulananthan and Vanniyasingam v Secretary of State for the Home Department [2004] Imm AR 112 at 132, per Laws LJ.

102. Nationality, Immigration and Asylum Act 2002, s 101(1); CA v Secretary of State for the Home Department [2004] INLR 453; AG v Secretary of State for the Home Department (Turkey - CA - fresh evidence) [2005] UKIAT00014, para 7.

103. See eg Oleed v Secretary of State for the Home Department [2003] Imm AR 499; Koci $v$ Secretary of State for the Home Department [2003] EWCA Civ 1507; Vijayanth $v$ Secretary of State for the Home Department [2004] EWCA Civ 1161; Nirmalanathan $v$ Secretary of State for the Home Department [2004] EWCA Civ 1380; Pisa v Secretan: of State for the Home Department [2004] EWCA Civ 1443; Ndlovu $v$ Secretary of State for the Home Department [2004] EWCA Civ 1567. The number of appeals from substantive IAT determinations to the Court of Appeal has in recent years comprised a significant part of the Court of Appeal's caseload when compared with other tribunal systems; in 2004, the Court of Appeal disposed of 133 appeals against IAT determinations compared with 16 appeals against the Social Security Commissioners: Department for Constitutional Affairs Judicial Statistics Annual Report 2004 (Cm 6565, 2005).

104. Arshad v Secretary of State for the Home Department [2001] EWCA Civ 587 at [20], per Laws LJ.

105. ' $P$ ' and ' $M$ ' $v$ Secretary of State for the Home Department [2004] EWCA Civ 1640 at [36], per Lord Woolf. 
proportion of the total volume of judicial review claims received by the Administrative Court. ${ }^{106}$ At the time of the 1999 Act, the government recognised the important function of judicial review in clarifying points of law but also argued that 'having a large number of unnecessary, vexatious and useless judicial reviews ... simply creates delay, expense and is counter productive'. ${ }^{107}$ By way of compromise, the 2002 Act replaced the ordinary judicial review process with a quick, paper-only statutory review procedure under which the IAT's refusal of permission may be subject to review by a single judge of the Administrative Court for any error of law (see above Figure 1). ${ }^{108}$

Despite the IAT's efforts to improve the efficiency and timeliness of decisionmaking and the introduction of statutory review, the decision to move to a single-tier appeal reflects continuing governmental dissatisfaction with the operation of the appeal structure. The 2004 Act therefore merges the two tiers of the old appeal system - adjudicators and the IAT - together to form the AIT (see above Figure 2). Appeals under this system, which came into effect in April 2005, are determined initially by a single immigration judge. New procedural rules emphasise the importance of speed and finality throughout the appeal process. ${ }^{109}$ From the determination of an appeal by the AIT, either party to the appeal may apply to the Administrative Court, on the grounds that the tribunal made an error of law, for an order requiring the AIT to reconsider its decision. ${ }^{110}$ Alternatively, the Administrative Court may, if it thinks that the appeal raises an important point of law, refer the appeal to the Court of Appeal. ${ }^{111}$ The single tier of appeal will remove the loops within the system through which appeals may be bounced between adjudicators, the IAT and the Administrative Court and through the introduction of more active case

106. Thomas, above $\mathrm{n} 17$, at 506-509.

107. Special Standing Committee on the Immigration and Asylum Bill 1999, col 1413, 11 May 1999 (Mike O'Brien MP, Minister of State).

108. Nationality, Immigration and Asylum Act 2002, s 101(2). See also $R$ (' $M$ ' and ' $G$ ') $v$ Immigration Appeal Tribunal and the Secretary of State for the Home Department [2005] 2 All ER 165. In 2003, the Administrative Court disposed of 320 applications for statutory review under the 2002 Act of which 61 were allowed and 259 dismissed; in $2004,1,731$ statutory review applications had been disposed of, 311 of which were allowed and 1,420 were dismissed. The introduction of statutory review was in part responsible for the reduction in the volume of judicial review claims from 5,949 in 2003 to 4,207 in 2004. See Department for Constitutional Affairs, above nn 4 and 104.

109. See Department for Constitutional Affairs Asylum and Immigration Tribunal Procedure Rules, and Judicial Titles Order Consultation Paper 27/04 (London: DCA, 2004); the Asylum and Immigration Tribunal (Procedure) Rules 2005, SI 2005/230. For the change in judicial titles, see Asylum and Immigration Tribunal (Judicial Titles) Order 2005 , SI 2005/227. One uncertain issue concerns the future role of the 60 lay members who previously sat on IAT appeal panels: as the IAT determined appeals from legally qualified adjudicators, the presence of lay members appeared anomalous. During the debates over the 2004 Act, the government resisted Lords amendments that the majority of appeals be determined by a three-person panel - legally qualified member and two lay members - because of the resource implications.

110. Asylum and Immigration (Treatment of Claimants, etc) Act 2004, s 26, inserting new s 103A into the Nationality, Immigration and Asylum Act 2002. See also CPR 54.28-54.35. 111. Asylum and Immigration (Treatment of Claimants, etc) Act 2004, s 26, inserting new s $103 \mathrm{C}$ into the Nationality, Immigration and Asylum Act 2002. 
management by the immigration judiciary to identify and address the key issues in appeals earlier. The intention is that under the 2004 Act, appeals will take a maximum of 15 weeks. ${ }^{112}$

When compared with other tribunal systems, the introduction of a single tier of appeal may appear somewhat unusual. After all, a two-tier appeal system is the established model for appellate systems which handle high volumes of appeals such as the social security appeal system. ${ }^{113}$ It is also the model to which other systems aspire, even those jurisdictions such as mental health review tribunals which handle a lower caseload than the asylum appeal system. ${ }^{114}$ Furthermore, the two-tier model provides for the basis for the new unified tribunal service which will include an administrative appeals tribunal to determine appeals against first instance appeal decision. ${ }^{15}$ The introduction of a single tier of appeal would also appear to run directly contrary to the government's own concept of proportionate dispute resolution, which encapsulates the notion that the formality, length, cost and complexity of redress mechanisms should be in proportion to the needs and seriousness of particular kinds of dispute. ${ }^{116}$ Decisions affecting fundamental rights, including the right to life, should arguably be subject to more anxious scrutiny than that offered by a single merits appeal backed up by review for error of law. However, the move to a single tier of appeal is to be clearly associated with the policy context of asylum appeals. The government's justification has been that a single tier of appeal will combat abusive appeals by reducing the opportunities through which unmeritorious appellants may exploit the process in order to delay the final resolution of their appeal as well as reducing costs and remove the incentive for future abuse of the system.

In removing one tier of the appeals process, the 2004 Act introduces new processes into the appeal structure to ensure oversight of decision-making and promote consistency. Specially convened panels of three or more legally qualified AIT members are able to promulgate both starred and country guideline determinations. In recognition of the higher status of such determinations, there is a direct right of appeal to the Court of Appeal. ${ }^{117}$ The intention of the 2004 Act is that the new AlT will adopt a proactive approach under which important problems and issues are identified and legal panels convened to provide authoritative guidance to ensure consistency through both country guideline and starred determinations. The role of the former IAT

112. 660 HL Official Report (5th series) col 996, 4 May 2004.

113. On social security appeals, see $N$ Wikeley 'Burying Bell: Managing the Judicialisation of Social Security Tribunals' (2000) 63 MLR 475; D Bonner 'From whence the Social Security Commissioners? The creation of the National Insurance Commissioner and the Industrial Injuries Commissioner' (2002) 9 JSSL 11.

114. The Department of Health Improving Mental Health Law: Towards a New Mental Heath Act (London, DoH, 2004) p 34 proposes to establish a Mental Health Appeal Tribunal to determine appeals on a point of law from Mental Health Review Tribunals and thereby provide a further specialist forum to ensure the law is applied correctly.

115. Department for Constitutional Affairs, above $\mathrm{n} 3$, paras 7.14-7.21.

116. On proportionate dispute resolution, see Department for Constitutional Affairs, above $\mathrm{n} 3$, paras $2.1-2.13$.

117. Asylum and Immigration (Treatment of Claimants, etc) Act 2004, s 26, inserting new s 103E into the Nationality, Immigration and Asylum Act 2002. 
members will also be different under the new system: as 'senior immigration judges' they will provide judicial management and leadership within the regional organisation of the AIT and provide legal expertise in hearing centres. ${ }^{118}$ Whether these changes comprise a sufficient to compensate for the removal of the second tier of the appeal process remains to be seen. The 2004 Act also establishes the new position of the 'designated immigration judge' whose responsibilities include the 'training, appraisal and mentoring' of Tribunal members. ${ }^{119}$ However, it is arguable that this quality control mechanism should have been introduced irrespective of the move to a single tier in order to improve Tribunal decision-making.

The decision to introduce a single tier of appeal should also seen in the context of the government's original intentions for the 2004 Act which initially contained perhaps the most wide-ranging ouster clause ever considered by Parliament. The effect of this extensive ouster clause would have been to insulate decisions of the new AIT from any form of scrutiny by the higher courts review except on the extremes of bad faith or dishonesty. ${ }^{120}$ The purpose of this controversial measure was to have reduced further the scope for using legal processes as delaying tactics by excluding ordinary higher court oversight of tribunal decision-making on the grounds of, inter alia, error of law and procedural unfairness. In light of the considerable opposition aroused to this proposal, the government replaced the ouster clause with a modified statutory review process before the Administrative Court. ${ }^{121}$

While conceding oversight of tribunal decision-making by the higher courts, the government has also ensured that the new procedure is to be tightly controlled. The time limits for review applications is five days for appellants present in the United Kingdom unless the court thinks that the application could not reasonably practicably have been made within that period. ${ }^{122}$ For applicants subject to the fast-track appeals process, this time limit is reduced further to only two days. ${ }^{123}$ Review applications may only be made once in relation to an appeal and are to be determined by reference only to written submissions. ${ }^{124}$ If the

118. Lord Falconer, Speech to the Immigration Appellate Authority Residential Conference, 28 June 2004.

119. Asylum and Immigration (Treatment of Claimants, etc) Act 2004, Sch 1, para $3(1)(\mathrm{c})(\mathrm{i})$.

120. See A Le Sueur 'Three strikes and it's out? The UK government's strategy to oust judicial review from immigration and asylum decision-making' [2004] PL 225.

121. Opposition to the ouster clause came from: parliamentary select committees, including the House of Commons Constitutional Affairs Select Committee, above n 83, ch 6; and the Joint Committee on Human Rights Fifth Report: Asylum and Immigration (Treatment of Claimants, etc) Bill (HL 35 HC 304, 2003-04); members of the House of Lords; the judiciary, see Lord Woolf 'The Rule of Law and a Change in the Constitution' [2004] CLJ 317; and the legal profession. The ouster clause was itself approved by the House of Commons: see 418 HC Official Report (6th series) cols 661-708, 1 March 2004. For an assessment of this episode see R Rawlings 'Review, Revenge and Retreat' (2005) 68 MLR 378.

122. Asylum and Immigration (Treatment of Claimants, etc) Act 2004, s 26, inserting new s $103 \mathrm{~A}(3)$ into the Nationality, Immigration and Asylum Act 2002.

123. Asylum and Immigration (Fast Track Time Limits) Order 2005, SI 2005/561.

124. Asylum and Immigration (Treatment of Claimants, etc) Act 2004, s 26, inserting new s $103 \mathrm{~A}(2)$ and (5) into the Nationality, Immigration and Asylum Act 2002. An interim transitional mechanism will operate under which review applications will initially be 
Administrative Court orders that the appeal be reconsidered, then the AIT must first decide whether the original Tribunal made a material error of law; if it decides that there was no material error of law, then the original determination will stand. ${ }^{25}$

This truncated statutory review procedure does not offer the same procedural advantages as ordinary judicial review procedure. ${ }^{126}$ It may, nevertheless, be more appropriate in the context of a tribunal adjudication system. 'Retail' or 'bureaucratic' judicial review of mass individualised decisions, as illustrated by statutory review, is a very different form of litigation from 'policy' or 'highprofile' judicial review of public policy. ${ }^{127}$ It typically concerns solely the individual claimant's interests and does not raise any broader issues affecting the public interest. The function of the review is not to decide the answer to any arguable point of law or examine the legality of public policy but simply to determine whether, as in the asylum context, the tribunal committed any arguable error of law. The review is only one aspect of the whole adjudication process and not determinative of the substantive issue as to whether or not the claimant is a refugee; a successful review against an AIT decision will mean that the appeal has to be re-heard by the AIT. Given the need for expedition in the handling of review applications, the statutory review process offers a greater prospect of finality than the cumbersome procedure of judicial review. Furthermore, as the Administrative Court is fully aware of the need for anxious scrutiny, oral submissions would be unlikely to add significantly to written submissions. ${ }^{128}$ The justification for retaining such oversight is that in there is a continuing need for a judicial assessment of mass tribunal decision-making in this difficult and high-pressure adjudicative system.

There is, however, one major difference between the statutory review procedures under the 2002 and 2004 Acts: review applications under the 2004 Act are subject to a system of retrospective legal aid funding. ${ }^{129}$ Legal aid is only to be awarded retrospectively at the end of the process, usually by the tribunal judge on reconsideration of the appeal after a successful review decision by the Administrative Court. If the Administrative Court orders the AIT to reconsider its decision because of an error of law, legal aid will only be awarded

determined by senior immigration judges (formerly IAT Vice-Presidents) to ensure that the Administrative Court is not overwhelmed by the number of review applications. This interim filter is to operate until the volume of challenges diminishes. See Asylum and Immigration (Treatment of Claimants, etc) Act 2004, Sch 2, para 30.

125. Asylum and Immigration Tribunal (Procedure) Rules 2005, SI 2005/230, r 31(2). 126. Normal judicial review procedure includes: a time limit of three months; an initial paper consideration to determine whether or not the claim should be granted permission to proceed; a right to renew this application orally if refused on the papers; a right of appeal against the refusal of permission to the Court of Appeal; a full oral hearing of the substantive issue; and then a right of appeal, with permission, to the Court of Appeal. See M Fordham 'Judicial Review: the new rules' [2001] PL 4.

127. P Cane 'Understanding Judicial Review and its Impact' in M Hertogh and S Halliday (eds) Judicial Review and Bureaucratic Impact: International and Interdisciplinary Perspectives (Cambridge: Cambridge University Press, 2004) pp 18-19.

128. See $R$ (' $M$ ' and ' $G$ ') $v$ Immigration Appeal Tribunal and the Secretary of State for the Home Department [2005] 2 All ER 165.

129. Asylum and Immigration (Treatment of Claimants, etc) Act 2004, s 26, inserting new s 103D into the Nationality, Immigration and Asylum Act 2002. 
automatically if the AIT's reconsideration of the appeal goes in the appellant's favour. If reconsideration of an appeal by the AIT is unsuccessful for an appellant, then legal aid will only be awarded if the Tribunal is satisfied that at the time the review application to Administrative Court was made the case had significant prospects of success. ${ }^{130}$ In other words, representatives will not know in advance whether legal aid will be awarded for either a review application to Administrative Court or the reconsideration of an appeal by the AIT.

The government has sought to justify retrospective funding on the basis that it will discourage weak applications by requiring representatives to assess carefully the merits of a claim before proceeding with an application - because the representative will have to bear some of the risk involved if funding is not subsequently granted - and therefore ensure that public money is focused on applicants with genuine claims. ${ }^{131}$ In response, it has been argued that the introduction of retrospective funding, which is both unprecedented and unique to asylum and immigration cases, is likely to have a negative impact on appellants as representatives will have to undertake a commercial assessment of the level of risk they are able to undertake. ${ }^{132}$ It may, for instance, be unrealistic to assume that representatives will be able to prepare adequately for a re-hearing of an appeal - prepare new witness statements, new expert evidence, up-to-date country materials - without the certainty of knowing that such work will be funded. In particular, by making representatives undertake the risk that they will not receive payment for their work may mean that they will refuse to represent individuals with reasonable cases. Furthermore, the level at which the test for retrospective funding has been set - was there a significant prospect of success when the review application was made? - is too high as it may exclude not only unmeritorious cases but also those which appeared to have a reasonable chance of success but were nevertheless ultimately unsuccessful. 'Lawyers considering whether applicants face possible human rights concerns, if deported, should not have to gamble on funding decisions.' 133

Although the government was compelled to retreat in the political debate over the ouster clause and concede judicial oversight by the Administrative Court of AIT, it has sought to confine the operation of the new review procedure by introducing retrospective legal aid funding. While the new review procedure may serve the important symbolic function of retaining the historic supervisory role of the higher courts, the effect of the new legal aid arrangements may achieve much the same effect as the ouster clause in terms of restricting access to the courts.

130. The Community Legal Service (Asylum and Immigration Appeals) Regulations 2005, SI 2005/966.

131. Department for Constitutional Affairs The Asylum and Immigration Tribunal The Legal Aid Arrangements for Onward Appeals Consultation Paper 30/04 (London: DCA, 2004).

132. House of Commons Constitutional Affairs Committee Fifth Report: Legal aid: asylum appeals (HC 276-II, 2004-05).

133. Above n 133, para 31. 


\section{TRIBUNALS AND POLICY IMPLEMENTATION}

To gain a better appreciation of the decision to introduce a single tier of appeal, we might consider the role of tribunals from the governmental perspective, ie that tribunals comprise part of the decision-making process in securing the implementation of policy goals. In the asylum context, as implementation implies recognition of genuine claimants and removal of unsuccessful claimants, the timeliness and cost-effectiveness of the process are of considerable importance for the following reasons. The longer the process becomes, then the higher the costs become in terms of supporting and accommodating applicants and the less likely removal becomes irrespective of the final outcome of a claim. Furthermore, the absence of an effective removals policy may encourage further unmeritorious applications. While the number of removals has increased from 9,000 in 2000 to 12,430 in 2004 (see above Table 1), these levels are nevertheless substantially lower than the total number of refused claimants. ${ }^{134}$ The reform of the appeal structure may then reflect the desire to speed up the process in order to effectuate removal of failed claimants and reduce costs.

There is, however, significant disagreement over precisely where the causes of delay within the system are to be located. While the government's point of view is that it has been the appeal process that provides the opportunities to delay finality, from the Tribunal's perspective the failure has been the Home Office's inability to implement tribunal decisions. As the IAT has noted: 'the Secretary of State does not, in the majority of cases, attempt promptly to enforce decisions of the immigration appellate authorities. Broadly speaking, an adverse decision ... has no immediate effect on the claimant's continued presence in the United Kingdom. ${ }^{135}$ The failure of the Home Office to enforce appeal decisions has in turn given rise to concerns that appeal outcomes are often rendered hypothetical because of the remote possibility of unsuccessful appellants being removed. ${ }^{136}$

The available evidence suggests that the length of the appeal process is only one and not even the principal reason why an effective removal policy has proved so elusive. Other reasons include: protracted delay in the system owing to a lack of co-ordination between Home Office and the Immigration Service

134. These statistics do not include those claimants who return voluntarily to their country of origin. While the volume of removals is low, the Immigration Service has, however, removed some asylum appellants before the final determination of their claim in either flagrant or incompetent defiance of court injunctions not to do so: the best known example is $M v$ Home Office [1994] 1 AC 377 but for a more recent example see $R$ (Dhillon) v Secretary of State for the Home Department (reported in 'Bungled deportation costs $£ 20,000$ ' The Times, 27 August 2004 but otherwise unreported) in which an Indian asylum claimant was returned to India despite an injunction from the Administrative Court not to do so.

135. Devaseelan $v$ Secretary of State for the Home Department (starred determination) [2003] Imm AR 1 at 10.

136. However, in Number $19 \mathrm{v}$ Secretary of State for the Home Department [2001] 01TH00093, para 44, the IAT stated that: '[n]ormally, the appellate authority is bound to assume that the respondent will enforce removal and that the appeals are not academic exercises.' 
concerning decision-making and enforcement; practical barriers to removal, such as the lack of appropriate travel documents and the reluctance of some source countries to accept the return of their own nationals; claimants who are 'non-returnable' owing to conditions in their country; and, finally, the inability of the Immigration Service to locate claimants who abscond. ${ }^{137}$ In relation to the timeliness of decision-making, it would appear that the tribunal system has improved the speed at which appeals are determined. ${ }^{138}$ While the Home Office has also considerably improved the speed with which new applications receive an initial decision, this has been at the expense of older applications caught up in the backlog of undecided claims - which peaked at 125,000 in 1999 - many of which have had to wait months and even years for an initial decision. ${ }^{139}$ It is also worth noting that until 2005 the Home Office did not seek to remove individuals recognised as refugees who, owing to a change of conditions in their country of nationality, could subsequently return in safety. After all, the cessation clause of the Refugee Convention implies that refugee status is envisaged as a temporary protection during a period of risk and not a permanent immigration status. ${ }^{140}$

The real difficulty with removing unsuccessful claimants would not therefore appear to be length of the appeal process but the delays which arise between the final determination of appeals and the removal of unsuccessful appellants. Appeals clearly require time in order to be effective in terms of the formal preparation of appeals, collecting evidence such as medical report or country expert report and the arrangements for a hearing. Furthermore, some delays have arisen because of the rate at which appeals have been remitted by the IAT for rehearing. Nevertheless, the problems with removing failed applicants would appear to be more a consequence of both practical difficulties of removal and lack of effective administration by the Home Office than delays within the appeal process. In other words, while the government has continuously reformed the appeal process to reduce delays, it is doubtful

137. House of Commons Home Affairs Committee Asylum Removals (HC 654, 200203) paras 49-66. See also National Audit Office Returning failed asylum applicants (HC 76, 2005-06); C Phuong 'The removal of failed asylum seekers' (2005) 25 LS 117. 138. For instance, during $2003-04,64 \%$ of applications received a final appeal decision within six months compared with $43 \%$ between 2001 and 2003. See National Audit Office, above n 7, p 25; Home Office Asylum Statistics 2003, p 5.

139. For instance, in $2003-04$, over $80 \%$ of applications received an initial decision within two months compared with an average of 22 months in 1997. See Home Office Asylum Statistics 4th Quarter 2004 United Kingdom (2004) p 4.

140. Refugee Convention 1951, art 1C(5). While the Immigration Rules (HC 395, 1994) para 330 state that refugees will be granted limited leave to enter, the normal practice has been for the Home Office to grant indefinite leave to remain even for refugees from countries where the situation is fluid, such as Turkey and Sri Lanka. For comment by the IAT, see $T J v$ Secretary of State for the Home Department (risk-returns) Sir Lanka CG [2002] UKIAT01869, para 9; Secretary of State for the Home Department v IA HC KD RO HG (risk - guidelines - separatist) Turkey CG [2003] UKIAT00034, para 47. In February 2005, the Home Office Controlling our borders: Making migration work for Britain (Cm 6472, 2005) para 39, announced that refugees would in future be granted temporary rather than indefinite leave to remain while it reviews whether the country situation has improved; if the situation has not improved within five years, then they would be granted indefinite leave to remain. 
whether this alone will secure effective removal of unsuccessful appellants if the causes of such delay are largely to be found elsewhere.

If so, then the motivation behind the reforms may be found in the short-term electoral politics of asylum. Having overseen the increase in asylum applications since 1997 and having since then attempted twice to reform the system, the Labour government, acutely conscious of criticisms that the system was in chaos, felt compelled by the political imperative of asylum to undertake a more radical reform to restore the perceived lack of public confidence in the system. ${ }^{14 l}$ To underscore this argument, it is apparent that the decision to move to a single tier of appeal came direct from the Prime Minister's office. This political impetus can also be seen reflected in the perfunctory consultation exercise concerning the new proposals. ${ }^{142}$

It is also important not to overlook the influence of related episodes in the development of government policy toward appeal rights. First, there was the pressure arising from additional costs of an estimated $£ 500$ million borne by the taxpayer arising from the backlog of undecided claims; some reform was needed to provide public re-assurance that costs would in future be reduced. ${ }^{143}$ Secondly, the introduction of the new system also followed the Home Secretary's announcement of an amnesty in 2003 for 15,000 families, which represented a "clearing of the decks" before the introduction of tough new measures' ${ }^{144}$ Both of these episodes were, however, to some extent the responsibility of the Home Office itself. The costs arising from the backlog could have been avoided if there had been investment in sufficient staff and resources. ${ }^{145}$ Furthermore, the amnesty, or mass settlement of appeals, was in part a response to increased costs incurred as a result of the Home Office's concession concerning the introduction of the separate human rights appeals in 2000 . While the new human rights appeal was to be available only to individuals who lodged asylum after October 2000, in Pardeepan the Home Office conceded that individuals who had made asylum claims before that date could nevertheless apply to the Home Office for a decision on human rights ground which would then generate a separate human rights appeal. ${ }^{146}$ The

141. See especially the speech by Tony Blair PM to the Labour Party Conference, 30 September 2003.

142. The decision to introduce a single tier of appeal was originally announced by the Home Secretary in Home Office press release 144/2003 'Asylum applications down by a third - Home Secretary welcomes significant progress' 22 May 2003 which stated that officials had been asked to draw up further legislative measures. In October 2003, a 'consultation letter' comprising four substantive pages was published jointly by the Home Office and the Department for Constitutional Affairs New Legislative Proposals on Asylum Reform (London: Home Office and DCA, 2003) which allowed only three weeks for consultation as opposed to the normal 12 weeks. The Asylum and Immigration (Treatment of Claimants, etc) Bill was published in November 2003, while the response to the consultation, New Legislative Proposals on Asylum Reform: Consultation Report (London, Home Office and DCA, 2003) was published in December 2003.

143. National Audit Office, above n 7, pp 30-32.

144. Home Office press notice $295 / 2003$ 'Clearing the decks for tough new asylum measures - Home Secretary' 24 October 2003.

145. National Audit Office, above n 7, pp 30-32.

146. Pardeepan $v$ Secretary of State for the Home Department (starred determination) [2002] Imm AR 249. 
consequence was increased support costs while individuals could pursue successive appeal rights until the Home Office concluded that it was more costeffective to grant indefinite leave to remain to families in this position in order to save taxpayers' money on support and legal aid.

In summary, the reforms to the appeal structure and legal aid have been motivated by political considerations to enable the government to appear to be reforming a system which had previously been subjected to successive waves of legislative reforms and to cut costs. Select committees expressed concern that the government was legislating too quickly without any assessment of the impact of the most recent set of legislative reforms. ${ }^{147}$ Furthermore, they also expressed concern that the reforms did not seek to deal with the generally recognised problem of the poor quality of initial decision-making and that further changes to the appeal system should be contingent on improvements to initial decision-making. ${ }^{1+8}$ The political imperative to speed up the process, however, was too great even though the legislative solution would not appear to have been directed at the principal causes of delay.

\section{CONCLUSION}

The purpose of this article has been to evaluate the development, operation and reform of the asylum appeal process. This focus has been justifiable in light of the important function of this particular appellate system in deciding whether or not removal would breach either the Refugee Convention or the ECHR. The broader significance of tribunals for reviewing administrative decision-making cannot be disputed. In terms of the volume of appeals they handle, tribunals are amongst the most important mechanisms for ensuring legal accountability of the administrative state. Recent governmental initiatives to establish a unified tribunal service to enhance the independence and expertise of tribunals reflect the importance of tribunals in resolving disputes between the individual and the state as well as a broader shift within government toward making public organisations more public-focused. ${ }^{149}$

As a device for ensuring administrative justice, tribunal adjudication systems are informed by a range of competing values and pressures. In one sense, tribunals

147. See eg House of Commons Constitutional Affairs Select Committee, above $n 83$. For instance, measures introduced by the 2002 Act had only just come into force in 2003 when further reforms were announced. The Immigration and Asylum Act 2002, s 157 itself contained a 'Henry VIII' clause because the legislation had been so rushed that parliamentary draftsmen were unsure whether or not further modifications were required. Furthermore, the 2002 Act was not printed until three weeks after it received royal assent despite the immediate implementation the provisions conceming non-suspensive appeals: see $Z L$ and $V L v$ Secretary of State for the Home Department [2003] Imm AR 330 at 334-337. The tendency of government toward legislative hyperactivity and not to undertake post-legislative scrutiny is a broader problem of the law-making process: see generally House of Lords Select Committee on the Constitution Parliament and the Legislative Process (HL 173, 2003-04).

148. This was a main concern of the House of Commons Constitutional Affairs Committee, above $\mathrm{n} 83$, and the House of Commons Home Affairs Committee, above $\mathrm{n} 71$.

149. Department for Constitutional Affairs, above $\mathrm{n} 3$. 
must conform to a legal model of decision-making by seeking to ensure accurate and independent decisions through fair procedures. At the same time, from a governmental or bureaucratic perspective, tribunals must also provide an efficient and cost-effective adjudication process. Like virtually all public bodies, tribunals must pursue multiple, complex and sometimes contradictory goals. Responsibility for managing the arising tensions lies principally with policymakers. After all, government remains politically accountable for adjudication systems and for allocating resources to fund them. As government tends to view tribunal systems as part of the decision-making process for implementing policy, the design and operation of tribunals are likely to be conditioned by the policy objectives pursued by government. The structure of tribunals and the procedures they operate will be a consequence of political compromise rather than the application of administrative law principles; there is a close and continuing symbiosis between policy and process.

The experience of asylum appeals therefore illustrates a broader dilemma of administrative justice: how to reconcile the need for proper and effective consideration of each claim with the need to process speedily and efficiently a high volume of claims. It may simply be that the delivery of mass justice inevitably means that the quality of justice administered is diminished precisely because of the scale of the task. The development of the asylum appeals systems illustrates the intrinsic difficulty in securing an effective system of mass justice in light of the complex tensions arising between policy, administration and law.

Asylum, however, poses a particularly acute challenge to the imperatives of mass administrative justice. In light of the highly politicised nature of the issues involved, there is a constant and intractable tension between the need to ensure anxious scrutiny and concerns that abusive applicants will seek to exploit the procedures available to them. Furthermore, the system operates under severe practical constraints. The sketch of the appeal system drawn here does indeed highlight several weaknesses of the process - poor quality administration by the Home Office, administrative delay and inefficiency resulting in increased costs, inadequate primary decision-making, variable representation and lack of enforcement. As the Court of Appeal has noted: 'inevitably, it is an imperfect system. It is remarkable that it works as well as it does.' ${ }^{150}$ The reforms of the 2004 Act have not, however, been directed at improving the quality of the appeal process. If the government had sought to do so, then the need for legislation would have become redundant. After all, many of the required improvements - better primary decision-making and administrative competence, more time for tribunal members to hear and determine appeals and improved representation - do not require legislation to be implemented.

Finally, we might consider the implications of the reform of the asylum appeals system for our understanding of the role of law in this context. As administrative law mechanisms for overseeing administrative decision-making, tribunals have two essential functions: they undertake the practical task of determining individual appeals and, by providing external legal controls on executive decision-making, tribunals also perform an important role in legitimising governmental administration and policy. In doing so, tribunals

150. Subesh, Suthan, Nagulananthan and Vanniyasingam y Secretary of State for the Home Department [2004] Imm AR 112 at 140, per Laws LJ. 


\section{Legal Studies}

are not dissimilar from the ordinary courts. They are, though, perhaps more susceptible to political pressure than the courts because of their ambivalent position on the boundary between law and public administration. Motivated by political considerations to reduce delay and costs, the government's reforms to the asylum appeal system have abolished one tier of the appeal system and restricted legal aid. The appeal system must still seek to operate in accordance with legal principle but the consequence of these reforms has been to increase the difficulties in achieving fair and accurate decision-making. The reforms have, however, enabled the government to benefit from the symbolic reassurance provided by a tribunal system and to justify its inaction with respect to the improvement of primary decision-making. 